FIRST REPORT TO

\title{
THE U.S. CONGRESS
}

AND

\section{THE U.S. SECRETARY OF ENERGY}

FROM THE

NuClear Waste Technical Review BoARD

MARCH 1990 



\section{DISCLAIMER}

This report was prepared as an account of work sponsored by an agency of the United States Government. Neither the United States Government nor any agency thereof, nor any of their employees, make any warranty, express or implied, or assumes any legal liability or responsibility for the accuracy, completeness, or usefulness of any information, apparatus, product, or process disclosed, or represents that its use would not infringe privately owned rights. Reference herein to any specific commercial product, process, or service by trade name, trademark, manufacturer, or otherwise does not necessarily constitute or imply its endorsement, recommendation, or favoring by the United States Government or any agency thereof. The views and opinions of authors expressed herein do not necessarily state or reflect those of the United States Government or any agency thereof. 


\section{DISCLAIMER}

Portions of this document may be illegible in electronic image products. Images are produced from the best available original document. 


\section{UNITED STATES \\ NUCLEAR WASTE TECHNICAL REVIEW BOARD \\ 1111 18th Street, N.W., Suite 801 \\ Washington, D.C. 20036}

March 22, 1990

The Honorable Thomas S. Foley

Speaker of the House

United States House of Representatives

H-204 Capitol

Washington, D.C. 20515-6501

The Honorable Robert C. Byrd

President Pro Tempore

United States Senate

Hart Office Building, Suite 311

Washington, D.C. 20510-1902

The Honorable James D. Watkins

U.S. Secretary of Energy

U.S. Department of Energy

Forrestal Building

Washington, D.C. 20585

Dear Speaker Foley, Senator Byrd, and Secretary Watkins:

The Nuclear Waste Technical Review Board herewith submits its first report as required by the Nuclear Waste Policy Amendments Act of 1987, Public Law 100-203.

The Congress created the Board to provide scientific and technical advice on the Nation's spent nuclear fuel and high-level waste disposal program. The Board's examination of the Department of Energy's (DOE) program is to include a review of the DOE's characterization of Yucca Mountain as a potential repository for long-term disposal of nuclear waste. The Board also will oversee activities relating to the packaging and transportation of nuclear waste.

During the initial stage of its existence, the Board devoted itself to becoming familiar with the DOE program, to listening to assessments by the State of Nevada and others of the DOE's site characterization efforts, and to obtaining and reviewing technical and scientific information on the program.

At this time, the Board has no specific recommendations that require congressional action. It does, however, make a number of recommendations intended to aid the DOE in its effort to improve technical work being conducted at the site, to assist the DOE in its overall study plan, and to advise Congress and the Secretary of Energy on regulatory or legislative areas of potential future concern. 
The Board has made 24 recommendations, which are presented in three categories. The first category includes 17 technical and scientific recommendations. The Board recommends that the DOE take appropriate action to implement them. The second category comprises four strategic technical and non-technical recommendations that should be evaluated or implemented by the DOE. The third category contains three science policy recommendations, two of which the Board will address in concert with the DOE and appropriate regulatory agencies; the third recommendation deals with the impasse between the DOE and the State of Nevada. The Board concludes that unless the impasse is resolved, the Yucca Mountain Site cannot be characterized because needed scientific and technical work cannot proceed. The Board acknowledges recent action to resolve this impasse.

In the near future, the Board intends to consider issues discussed in two recently released documents: the Secretary of Energy's Report to Congress on Reassessment of the Civilian Radioactive Waste Management Program, and the Monitored Retrievable Storage Review Commission's Nuclear Waste: Is There a Need for Federal Interim Storage? These issues will impact the Department of Energy's high-level waste disposal program and, consequently, the future work of the Board.

We thank you for this opportunity to serve the Nation and the Congress. As our work progresses we hope to assist the Congress and the DOE in furthering the goal of safe, efficient, and timely disposal of high-level waste and spent nuclear fuel.

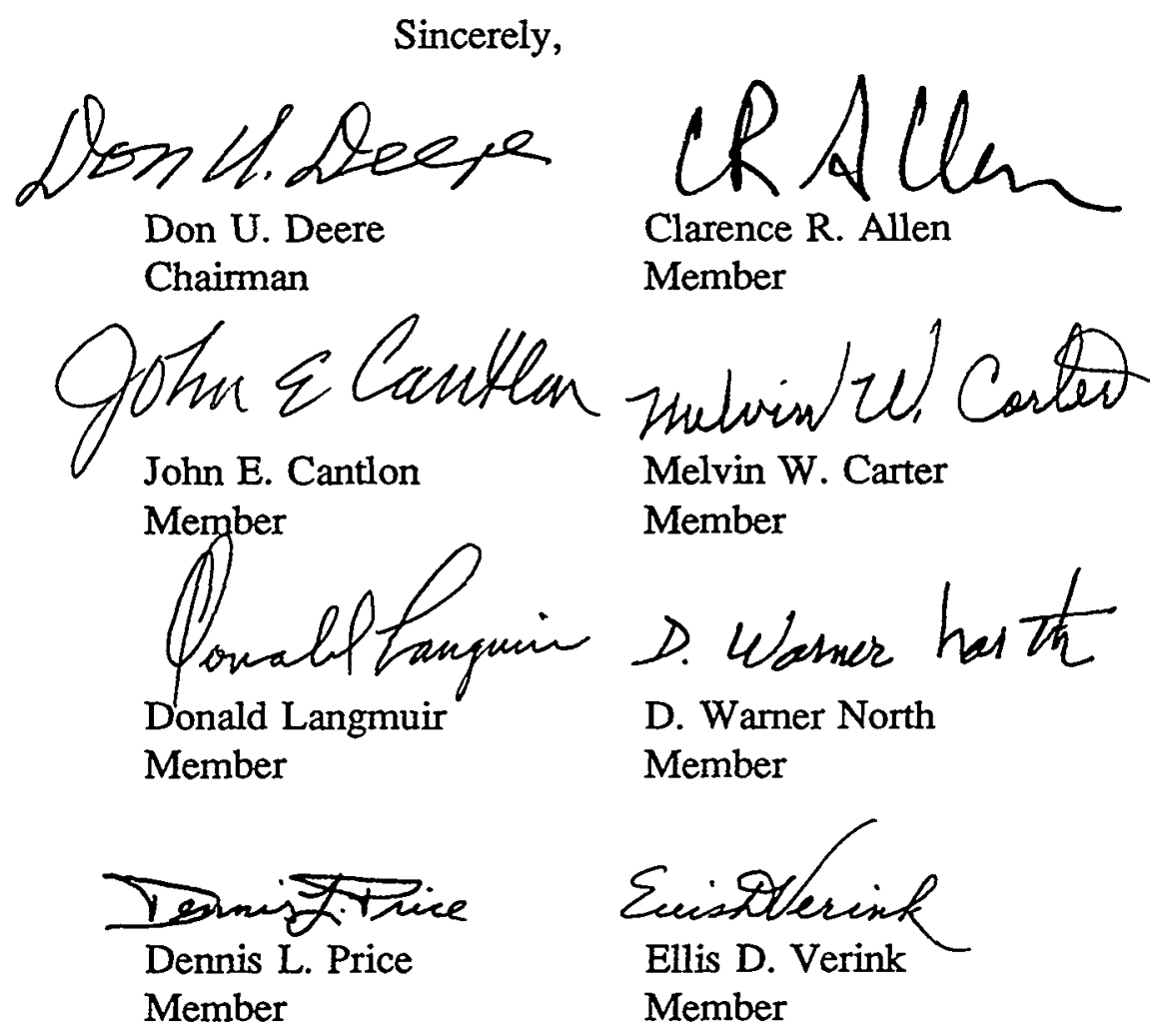




\section{Nuclear Waste Technical ReVIEW BoARD}

Members

Don U. Deere, Chairman

Clarence R. Allen

John E. Cantlon

Melvin W. Carter

Donald Langmuir

D. Warner North

Dennis L. Price

Ellis D. Verink

\section{NWTRB Staff}

Executive Director

William W. Coons

Professional Staff

Paula N. Alford

Sherwood C. Chu

Russell K. McFarland

Sidney J.S. Parry

Administrative Staff

Dennis G. Condie, Deputy Executive Director

Joanne E. Donnelly

Helen W. Einersen

Debra K. Hairston

Report Production Services

Nancy E. Derr

William D. Harrison

Rosalyn V. Demaree 


\section{Table of Contents}

\section{Transmittal Letter}

Nuclear Waste Technical Review Board Members

Executive Summary $\ldots \ldots \ldots \ldots \ldots \ldots \ldots \ldots \ldots \ldots \ldots \ldots \ldots \ldots \ldots \ldots \ldots \ldots \ldots \ldots \ldots$

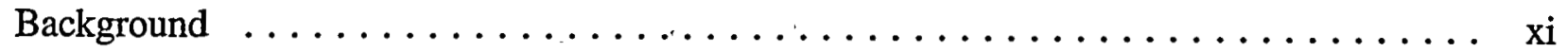

Role and Activities of the Nuclear Waste Technical Review Board $\ldots \ldots \ldots \ldots \ldots$ xii

Recommendations ........................... xiv

Technical and Scientific Recommendations . ............... xiv

Strategic Technical and Non-Technical Recommendations ............ xv

Science Policy Recommendations . . . . . . . . . . . . . . . . xvi

Cross-Cutting Issues for Future Inquiry $\ldots \ldots \ldots \ldots \ldots \ldots \ldots \ldots \ldots \ldots$ xvi

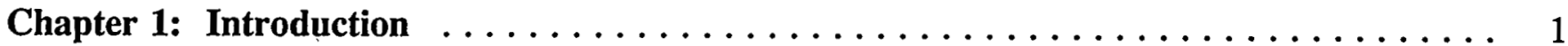

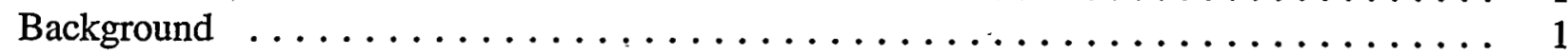

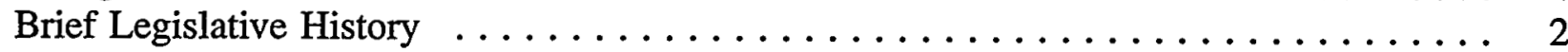

Legal and Regulatory Requirements $\ldots \ldots \ldots \ldots \ldots \ldots \ldots \ldots \ldots \ldots \ldots$

Board and Panel Composition . . . . . . . . . . . . . . . . . . . . . 4

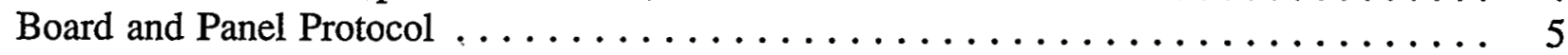

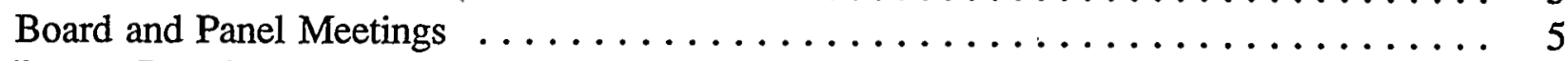

Recent Developments ............................. 6

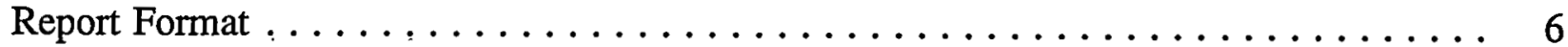

Chapter 2: Issues and Recommendations $\ldots \ldots \ldots \ldots \ldots \ldots \ldots \ldots \ldots \ldots$

Section 1: Structural Geology and Geoengineering ............... 10

Tectonic Features and Processes . . . . . . . . . . . . . . . . . 10

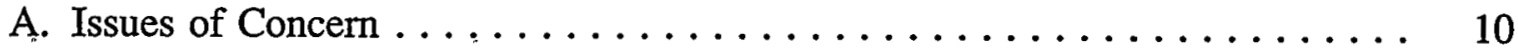

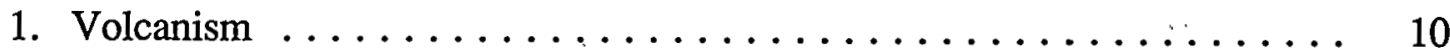

2. Seismicity and Faulting $\ldots \ldots \ldots \ldots \ldots \ldots \ldots \ldots \ldots \ldots \ldots \ldots \ldots \ldots \ldots$

3. Licensing Standards and Criteria Involving Geologic Issues ....... 12

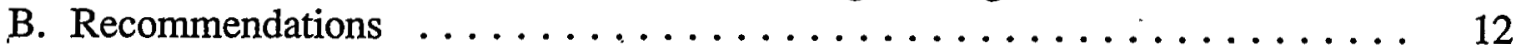

Geologic Block Evaluation: Exploratory Shaft Facility . . . . . . . . . 12

A. Issues of Concern .......................... 12

1. Shaft Construction ......................... 12

2. Exploration of the Ghost Dance Fault $\ldots \ldots \ldots \ldots \ldots \ldots \ldots \ldots, 12$

3. An East-West Exploratory Drift $\ldots \ldots \ldots \ldots \ldots \ldots \ldots \ldots \ldots . \ldots \ldots$

4. An Inclined Ramp into the East Side of the Yucca Mountain Block ... . 13 
5. Geologic Mapping of Shafts and Tunnels .............. 13

6. Exploration of the Softer Tuff Units ............... 13

B. Recommendations and Future Plans ................ 13

Section $2:$ Hydrogeology and Geochemistry $\ldots \ldots \ldots \ldots \ldots \ldots$

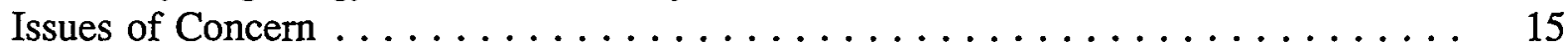

A. Recharge to the Unsaturated Zone $\ldots \ldots \ldots \ldots \ldots \ldots \ldots \ldots \ldots \ldots$

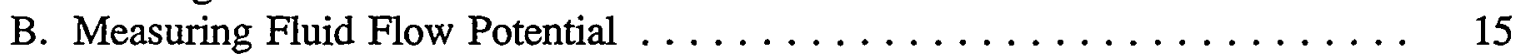

C. Hydrogeologic Models . . . . . . . . . . . . . . . . . . . 15

D. Moisture Movement in the Unsaturated Zone $\ldots \ldots \ldots \ldots \ldots \ldots$

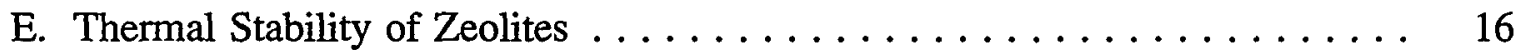

F. The Applicability of Laboratory-Measured $\mathrm{K}_{\mathrm{d}}$ (sorption) Values to the Prediction of Radionuclide Transport at Yucca Mountain . . . . . . . . . 16

G. Suggested Approaches to the Study of Radionuclide Adsorption by Tuff . . 17

Conclusions and Recommendations $\ldots \ldots \ldots \ldots \ldots$

Section 3: Risk and Performance Analysis ................... 20

Issues of Concern . . . . . . . . . . . . . . . . . . . . 21

A. Performance Allocation and Assessment . . . . . . . . . . . . . 21

B. Methodology for Assessing Expert Judgment . . . . . . . . . . . . . 21

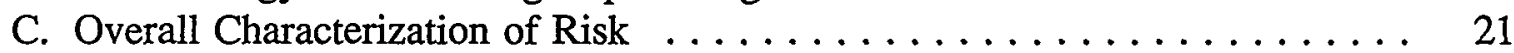

Recommendations and Future Plans ................... 22

Section 4: Containers and Transportation .................. 23

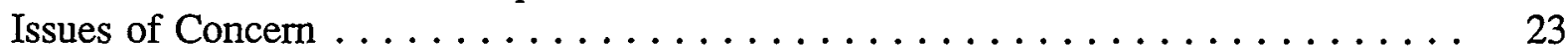

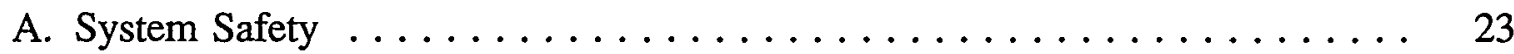

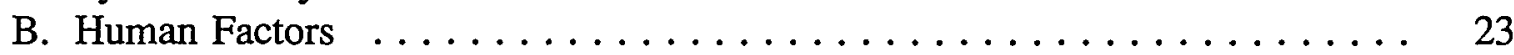

C. Risk Assessment and Management . . . . . . . . . . . . . . . 24

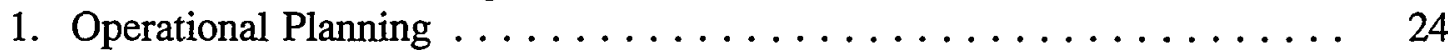

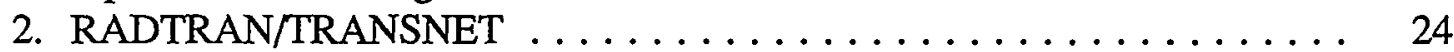

Recommendations ........................... 26

Section 5: Environment and Public Health $\ldots \ldots \ldots \ldots \ldots \ldots \ldots$

The Environmental and Public Health Program $\ldots \ldots \ldots \ldots 26$

A. Water Resources ......................... 28

B. Air Resources . . . . . . . . . . . . . . . . . . . . . . 29

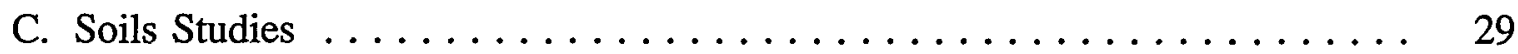

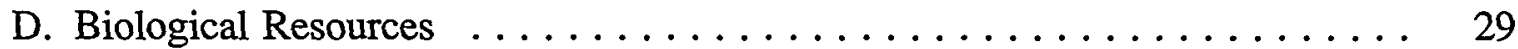

E. Cultural Resources . . . . . . . . . . . . . . . . . . . . 30

F. Radiological Studies . . . . . . . . . . . . . . . . . . . 30

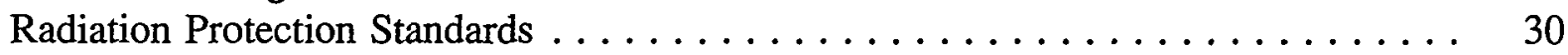

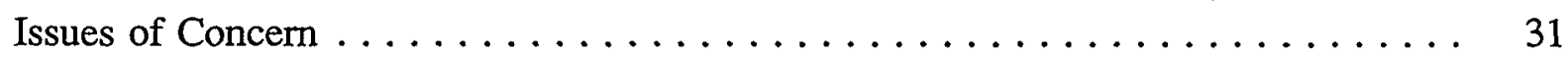

Recommendations ............................. 32

A. Environmental and Public Health Protection Program . . . . . . . . . 32

B. Regulatory Matters ........................ 32 


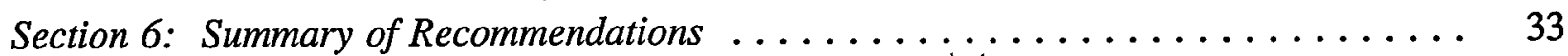

Technical and Scientific Recommendations . . . .............. 33

A. Mechanical Excavation . . . . . . . . . . . . . . . . . 33

B. Ghost Dance Fault $\ldots \ldots \ldots \ldots \ldots \ldots \ldots \ldots \ldots \ldots \ldots \ldots \ldots \ldots \ldots \ldots \ldots$

C. Early Exploratory Drifting $\ldots \ldots \ldots \ldots \ldots \ldots \ldots \ldots \ldots \ldots \ldots \ldots \ldots$

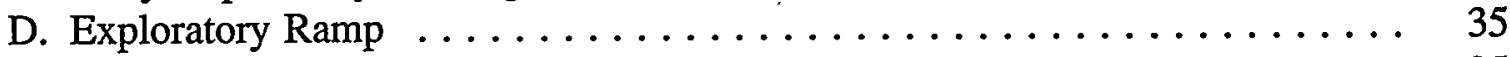

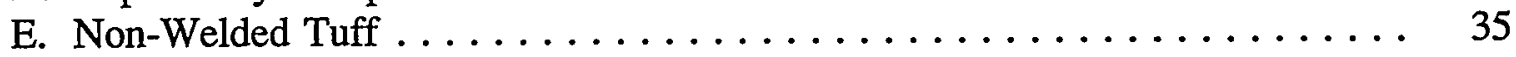

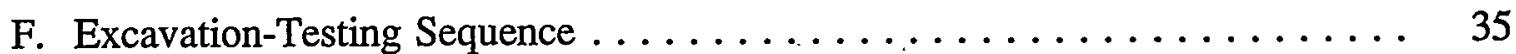

G. Unsaturated Zone Recharge $\ldots \ldots \ldots \ldots \ldots \ldots \ldots \ldots \ldots \ldots \ldots \ldots$

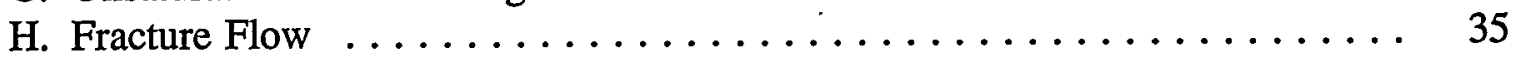

I. Hydrogeologic Modeling . . . . . . . . . . . . . . . . . 35

J. Calico Hills Hydrogeologic Properties $\ldots \ldots \ldots \ldots \ldots \ldots \ldots \ldots, \ldots \ldots$

K. Adsorption in Unsaturated Tuffs $\ldots \ldots \ldots \ldots \ldots \ldots \ldots \ldots \ldots \ldots \ldots \ldots \ldots \ldots$

L. Radionuclide Adsorption Workshop $\ldots \ldots \ldots \ldots \ldots \ldots \ldots \ldots \ldots . \ldots \ldots$

M. Performance Assessment Methodology . . . . . . . . . . . . . 36

N. Preliminary Performance Assessment $\ldots \ldots \ldots \ldots \ldots \ldots \ldots \ldots \ldots, 36$

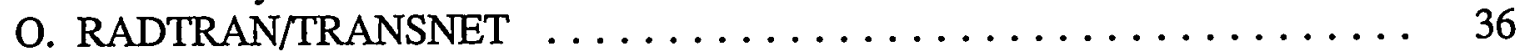

P. Risk Models User-Needs Assessment $\ldots \ldots \ldots \ldots \ldots \ldots \ldots \ldots \ldots \ldots 36$

Q. ${ }^{14} \mathrm{C}$ Release Mechanism ...................... 36

Strategic Technical and Non-Technical Recommendations . . . . . . . . . 36

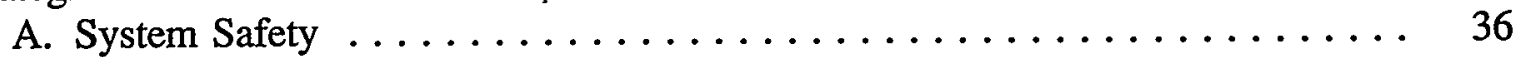

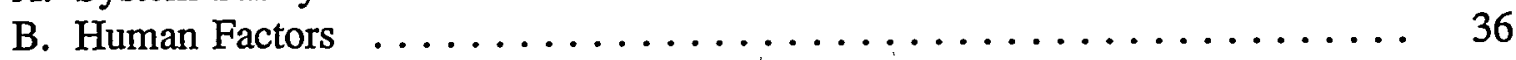

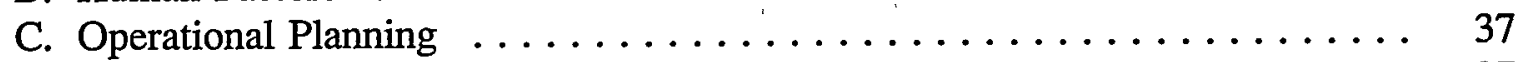

D. Environmental and Public Health Program $\ldots \ldots \ldots \ldots \ldots \ldots \ldots . \ldots 37$

Science Policy Recommendations . . . . . . . . . . . . . . . . . 37

A. DOE and State of Nevada Interactions $\ldots \ldots \ldots \ldots \ldots \ldots \ldots \ldots \ldots, 37$

B. The EPA Standard: 40 CFR $191 \ldots \ldots \ldots \ldots \ldots \ldots \ldots \ldots \ldots \ldots \ldots$

C. Consideration of Uncertainties in Setting Standards $\ldots \ldots \ldots \ldots \ldots \ldots$

Chapter 3: Cross-Cutting Issues for Future Inquiry $\ldots \ldots \ldots \ldots \ldots \ldots \ldots \ldots \ldots$

Issue 1: A Systems Engineering and Analysis Approach . . . . . . . . . . . . 39

Issue 2: The Relative Importance of Natural and Engineered Barriers . . . . . . . . . . 40

Issue 3: Thermal Loading of a Repository ................... 40

Issue 4: Repository Suitability and Licensing Standards $\ldots \ldots \ldots \ldots \ldots \ldots \ldots 41$

Issue 5: Current DOE Priorities $\ldots \ldots \ldots \ldots \ldots \ldots \ldots \ldots \ldots \ldots \ldots \ldots \ldots \ldots \ldots$

Appendix A: Public Law 100-203-December 22, 1987, Part E, Nuclear Waste Technical Review Board

Appendix B: Nuclear Waste Technical Review Board Members: Curricula Vitae

Appendix C: People Making Presentations Before the Nuclear Waste Technical Review Board

Appendix D: Panels and Working Papers

Appendix E: Guide to Scientific and Technical Terms 


\section{List of Figures}

Figure 1: Description of the Yucca Mountain Site $\ldots \ldots \ldots \ldots \ldots \ldots \ldots$

Figure 2: Functions and Duties of the Nuclear Waste Technical Review Board $\ldots \ldots \ldots 2$

Figure 3: Purpose of the Nuclear Waste Technical Review Board . . . . . . . . . . . . 3

Figure 4: Nuclear Waste Technical Review Board Powers . . . . . . . . . . . . . 4

Figure 5: MRS Review Commission Recommendations $\ldots \ldots \ldots \ldots \ldots$

Figure $6:$ The Secretary of Energy's Conclusions $\ldots \ldots \ldots \ldots \ldots \ldots \ldots \ldots$

Figure 7: OCRWM's Environmental Process for the Repository Site $\ldots \ldots \ldots \ldots$

Figure $8:$ Board Recommendations $\ldots \ldots \ldots \ldots \ldots \ldots \ldots \ldots \ldots \ldots \ldots \ldots \ldots$ 


\title{
Executive Summary
}

\author{
First Report \\ to the \\ U.S. Congress and Secretary of Energy \\ from the \\ Nuclear Waste Technical Review Board
}

\section{Background}

The disposal of the Nation's spent nuclear fuel and high-level waste has been studied for many years. The Nuclear Waste Policy Act of 1982 and the subsequent Nuclear Waste Policy Amendments Act (NWPAA) of 1987 provide the legislative framework under which the Department of Energy (DOE) must operate when evaluating potential sites for the geologic disposal of spent nuclear fuel and high-level waste. Additionally, the DOE must comply with regulations published by the Environmental Protection Agency (EPA) in 40 CFR 191, "Environmental Radiation Protection Standards for Management and Disposal of Spent Nuclear Fuel, High-Level and Transuranic Radioactive Wastes" and the Nuclear Regulatory Commission (NRC) in 10 CFR 60, "Disposal of High-Level Radioactive Wastes in Geologic Repositories." The DOE also operates under its own regulation, $10 \mathrm{CFR}$ 960, "General Guidelines for the Recommendation of Sites for Nuclear Waste Repositories."

The DOE has devoted considerable resources to this program, which is managed by the Office of Civilian Radioactive Waste Management (OCRWM). Disposal of spent nuclear fuel and high-level waste in a geologic repository has never before been done anywhere in the world. Since this is a first-of-a-kind facility, extreme care must be taken to ensure that all environmental and public health standards are met during its required long life.

Yucca Mountain was designated by the NWPAA as the sole site to be characterized for the disposal of spent nuclear fuel and high-level waste (see "Description of the Yucca Mountain Site"). It is important to recognize that Yucca Mountain has not been chosen for a permanent disposal site or repository. Rather, it is the candidate site to be characterized to determine whether or not it meets the myriad requirements set forth in existing regulations for the long-term disposal of spent nuclear fuel and high-level waste.

The radioactive waste to be emplaced in a repository will consist primarily of spent nuclear fuel from more than 70 commercial reactor sites. It is expected that existing nuclear power plants will produce approximately 87,000 metric tons of 


\section{Description of the Yucca Mountain Site}

Yucca Mountain is located in southern Nevada about 100 miles northwest of Las Vegas within the Great Basin. The site is in Nye County, Nevada, and includes land area controlled by: (1) The Bureau of Land Management (BLM), U. S. Department of the Interior; (2) Nellis Air Force Range, U.S. Department of Defense; and (3) the Nevada Test Site, U.S. Department of Energy. The first two areas have been withdrawn from public domain and are managed by the BLM. The Nevada Test Site has been withdrawn from the public domain but is reserved for use by the DOE. Yucca Mountain is in an arid region with mountain ranges and valleys, sparse vegetation, low rainfall, and limited population. It does not have surface drainage outside the Great Basin.

spent nuclear fuel during their lifetime. ${ }^{1}$ A small amount of commercial and defense high-level waste from reprocessing is also expected to be emplaced in the repository.

In December 1988, the DOE published the nine-volume, Site Characterization Plan, Yucca Mountain Site, Nevada Research and Development Area, Nevada, which is known as the site characterization plan or SCP. Supporting the SCP are numerous study plans that describe the procedures for gathering scientific data needed to determine whether the Yucca Mountain Site is suitable for spent nuclear fuel and high-level waste disposal. If the DOE determines the site is suitable, it must then demonstrate to the NRC that the site meets regulatory licensing criteria. Such criteria are intended to protect the health and safety of the public and to minimize environmental impacts.

\section{Role and Activities of the Nuclear Waste Technical Review Board}

The Nuclear Waste Technical Review Board (the Board), operating under the NWPAA and other expressions of congressional intent, has been charged with reviewing the technical and

\footnotetext{
${ }^{1}$ Commercial Nuclear Power 1989, DOE/EIA-0438, p. ix (Washington, D.C.: U.S. Department of Energy, Energy Information Administration, 1989).
}

scientific work performed by the DOE in its high-level radioactive waste and spent nuclear fuel disposal program. The Board must report its findings, conclusions, and recommendations to the Congress and the Secretary of Energy no fewer than two times each year.

The first meeting of the Board occurred March $7-8,1989$, at which time eight members were sworn in. Three members remain to be appointed. During the first meeting, the DOE briefed the Board on broad programmatic aspects of the waste disposal program. Secretary Watkins, U.S. Department of Energy, addressed the Board members and stated that he would welcome their advice. The Board met on three other occasions: June 26-28, 1989, in Las Vegas, Nevada; September 12-13, 1989, in Washington, D.C.; and December 12-13, 1989, in Denver, Colorado. During these meetings, the Board was briefed by representatives and contractors from the DOE, the State of Nevada, the Edison Electric Institute/ Utility Nuclear Waste and Transportation Program, and the Electric Power Research Institute. Additionally, several Board members attended informal meetings of the DOE and/or the NRC, where technical information was exchanged. Most Board members also attended national and international meetings on technical issues pertaining to radioactive waste disposal.

The Board has scheduled the following meetings to date in 1990: March 2-3 in Tucson, 
Arizona; and April 6-7 in Las Vegas, Nevada. The Board intends to explore a number of issues raised in this report in greater depth during these upcoming meetings. As part of that process, the Board plans to continue hearing the views of interested parties; including environmental and public interest groups, federal agencies, professional associations, and state, local, and Indian tribal governments.

The Board established five internal panels to address the substantial scientific and technical areas that must be analyzed when characterizing Yucca Mountain. These panels are: Structural Geology and Geoengineering, Hydrogeology and Geochemistry, Risk and Performance Analysis, Containers and Transportation, and Environment and Public Health. The panels refer their findings and recommendations to the full Board for further consideration. The panels, comprising two to six Board members each, met a total of seven times with the DOE, representatives of other federal agencies, and DOE contractors to pursue specific topics in greater depth.

Structural geology refers to the natural processes of volcanism, faulting, and earthquakes and related rock deformation. If it can be determined that volcanic activity is reasonably likely to occur within a repository or close enough to disrupt the site, then the site would be disqualified. Similarly, if scientists predict that faulting is reasonably likely to occur within a repository and would significantly disrupt it, the repository site would be disqualified. Geoengineering refers to the design, construction, and performance of the exploratory shaft facilities and underground openings at the repository.

Hydrogeology at the Yucca Mountain Site involves the study of fluid transport through the rock matrix and fractures. Hydrogeologists are concerned with possible engineering problems in repository construction, operation, and closure and with the rate of movement of groundwater that might transport radionuclides (atoms that are radioactive) from the repository to the accessible environment. Geochemistry as applied to the Yucca Mountain Site is concerned primarily with the potential migration of radionuclides to the accessible environment. Geochemists, therefore, are studying the chemical and physical properties of the minerals, rocks, and waters that might retard the migration of radionuclides from a repository.

Risk and performance analysis refers to the need to analyze those factors that could influence the long-term performance of the Yucca Mountain Site. Such analysis covers all areas and provides an integration of each scientific and technical aspect into a picture of the entire characterization effort. For example, if planned studies of volcanism do not provide information needed to determine the suitability of the Yucca Mountain Site, changes to the study plan should be made.

Issues addressed in the context of containers and transportation refer to the study of receptacles that could be used for the disposal of highlevel waste at the repository and the transportation issues inherent in moving radioactive waste to a disposal site from more than 70 commercial reactor sites nationwide and from defense facilities.

Environmental issues refer to the impact that development and operation of the repository will have on the air, water, cultural, and biological resources at the site for thousands of years to come. Public health issues refer to the potential effects on human health of repository development and operations, both during the period of development and operation and in the period after closure of the repository. The public health and environmental consequences of the transportation of spent nuclear fuel and high-level waste from point of origin to the repository are also of concern. 


\section{Recommendations}

The Board has a number of recommendations that are intended to assist the DOE in its efforts to improve the technical work being conducted at Yucca Mountain and to improve its overall study plan. None of these recommendations requires congressional action. Recommendations are presented in three categories: technical and scientific, strategic technical and non-technical, and science policy.

\section{Technical and Scientific Recommendations}

The Board's objective has been to identify the most important technical and scientific issues that the DOE should analyze further and to specify a possible course of action. The Board recommends that the DOE take action on the following 17 issues.

\section{A. Mechanical Excavation}

Maximize the use of the most modern mechanical excavation techniques in the recently initiated studies of alternative shaft and tunnel construction methods.

\section{B. Ghost Dance Fault}

Intersect the Ghost Dance Fault with an exploratory drift at more than one location.

\section{Early Exploratory Drifting}

Plan an exploratory drift in an east-west direction across the Yucca Mountain geologic block.

\section{Exploratory Ramp}

Continue studies for incorporating an exploratory ramp entering the Yucca Mountain geologic block from the east.

\section{E. Non-Welded Tuff}

Include in the exploratory program ample penetration of the softer, less permeable tuff units by borings, shafts, ramps, or tunnels.

\section{F. Excavation-Testing Sequence}

Develop innovative ways of coordinating and sequencing excavation and scientific testing.

\section{G. Unsaturated Zone Recharge}

Expand and accelerate the studies of snowmelt and rainfall infiltration into alluvium and nearsurface fractures.

\section{H. Fracture Flow}

Continue the sampling and analysis of ${ }^{3} \mathrm{H}$ and ${ }^{36} \mathrm{Cl}$ isotopes to gain a better understanding of the surface features that control the deep penetration of recharge.

\section{Hydrogeologic Modeling}

Approach hydrogeologic modeling in the program in a more systematic fashion, and validate models when new pertinent field data are made available.

\section{J. Calico Hills Hydrogeologic Properties}

Explore the Calico Hills tuff unit with surface borings and with the exploratory shaft facility. 


\section{K. Adsorption in Unsaturated Tuffs}

Study radionuclide adsorption in unsaturated tuffs over the range of temperatures and variable conditions of $\mathrm{pH}$, ionic strength, and competing and complexing aqueous ionic species concentrations expected at the site.

\section{Radionuclide Adsorption Workshop}

Organize a radionuclide adsorption workshop to determine the applicability of available radionuclide adsorption data on tuff and to establish additional research and model development needs.

\section{Performance Assessment Methodology}

Develop methodology to demonstrate performance assessments.

\section{N. Preliminary Performance Assessment}

Carry out preliminary performance assessment calculations to demonstrate that such computations are possible and to determine if any site characteristic has been detected that would disqualify the site.

\section{O. RADTRAN/TRANSNET}

Validate the RADTRAN model and some components in the TRANSNET package.

\section{P. Risk Models User-Needs Assessment}

Assess the needs of potential RADTRAN/ TRANSNET users with respect to what the various civilian radioactive waste program users want to accomplish and the levels of detail they require for different applications.

\section{Q. ${ }^{14} \mathrm{C}$ Release Mechanism}

Expand studies of ${ }^{14} \mathrm{C}$ release mechanisms and initiate a consultive program with the EPA and the NRC to examine the appropriateness of the ${ }^{14} \mathrm{C}$ limit.

\section{Strategic Technical and Non-Technical Recommendations}

Strategic technical recommendations involve value judgments about technical and non-technical factors. On such matters, the Board will attempt to explain the issues more clearly, suggest possible mechanisms or processes for addressing and/or resolving the issues, or make judgments on them. The Board makes the following four recommendations to the DOE in this category.

\section{A. System Safety}

Initiate a transportation system safety program.

\section{B. Human Factors}

Initiate a human factors program for transportation safety.

\section{Operational Planning}

Evaluate the use of risk-based planning tools in developing a broadbased and complete transportation operational plan.

\section{Environmental and Public Health Program}

Develop a systems approach to the Yucca Mountain ecosystem studies program so that each individual study is integrated into an overall environmental program. 


\section{Science Policy Recommendations}

Science policy recommendations involve decisions typically dealt with in the upper echelons of the Executive Branch or Congress. Such issues involve storage, disposal, and transportation of spent nuclear fuel; the development of EPA standards and NRC regulations; and the repository licensing process. Three recommendations are presented in this category.

\section{A. DOE and State of Nevada Interactions}

Continue efforts to resolve the present impasse on permitting of site characterization studies.

\section{B. The EPA Standard: 40 CFR 191}

Consider six modifications when EPA Standard: 40 CFR 191 is revised.

\section{Consideration of Uncertainties in Setting Standards}

Regulatory agencies should consider inherent uncertainties and limitations in geologic information and data projected for periods of tens of thousands of years in regard to the rigor of formulating acceptable and realistic environmental radiation protection standards.

\section{Cross-Cutting Issues for Future Inquiry}

In addition to presenting its 24 recommendations, the Board has identified a number of issues of potential impact to nuclear waste management. The first (the Nevada/DOE impasse) is of immediate concern. The Board will address the remaining five issues in the future.

\section{A. State of Nevada/DOE Impasse}

This issue emerges from one of the three science policy recommendations made by the
Board. Unless the impasse is resolved, the Yucca Mountain Site cannot be characterized because needed scientific and technical work cannot proceed. Implementation of the technical recommendations is important to facilitate site characterization activities.

\section{B. A Systems Engineering and Analysis Approach}

Systems engineering and analysis (SEA) is a set of procedures that provides a means of coordinating, integrating, and controlling large, complex scientific and engineering programs. SEA establishes procedures that integrate and control diverse technologies, which occur in complex tasks such as building a repository for the permanent disposal of spent nuclear fuel and high-level waste. It is a process that can analyze the technical and non-technical implications of decisions, provide for contingencies, and select optimal or nearly optimal solutions to problems that may arise. To be effective, however, SEA requires extensive coordination and advance planning.

The Board believes that incorporation of many of the key features of an effective SEA program could enhance the waste management program and therefore intends to work with the DOE on this issue in the future.

\section{The Relative Importance of Natural and Engineered Barriers}

The geologic repository will consist of engineered barriers and a geologic barrier that together will isolate spent nuclear fuel and high-level waste from the biosphere for at least 10,000 years. Where natural geologic barriers are deficient, it may be possible to increase the levels of waste isolation by adding extended-life engineered barriers.

The Board will explore with the DOE, the $\mathrm{EPA}$, and the NRC the potential advantages associated with developing extended-life engineered barriers. 


\section{Thermal Loading of a Repository}

Even under the best of circumstances, technical uncertainties will persist regarding the performance of any geologic repository. Uncertainty about a repository's long-term performance is related in part to thermal pulse, which is introduced when spent nuclear fuel is emplaced in the repository. This uncertainty may be decreased by reducing the thermal loading of the repository. The radioactive material in spent nuclear fuel can be allowed to decay or "cool" prior to disposal; less spent nuclear fuel can be put in each canister (at a planned spacing), or the spacing among waste canisters can be increased.

The Board will explore with the DOE the benefits gained by reducing thermal loading, balanced against the possible need for additional waste storage facilities, an increase in the number of waste packages, and the need for more repository capacity.

\section{E. Repository Suitability and Licensing Standards}

Licensing standards and criteria for the repository, as promulgated by the EPA and the NRC, must be adequately conservative on the side of safety and protection of the accessible environment. However, the standards should not impose

${ }^{2}$ Report to Congress on Reassessment of the Civilian Radioactive Waste Management Program (Washington, D.C.: U.S. Department of Energy, Office of Civilian Radioactive Waste Management, November 29, 1989). restrictions that would foreclose at the outset a candidate site subsequently shown to be suitable based on sound scientific considerations. In this light, the Board has been working with personnel from the EPA, the NRC, and the DOE. It will continue this activity in 1990.

\section{F. Current DOE Priorities}

The U.S. Secretary of Energy in his recent report to Congress concluded that to develop a technically sound integrated waste management system, the DOE needs to implement management improvements, to pursue an orderly program of scientific investigations that is not driven by unrealistic scheduling demands, and to establish a monitored retrievable storage (MRS) facility with more flexible linkages to the repository to allow early acceptance of spent nuclear fuel. $^{2}$

The Board believes that all three topics fit well into the concept of systems engineering and analysis, which allows the integration and control of diverse technologies and the establishment of priorities. The Board urges that high priority be given to the studies of the natural hazards of volcanism, faulting, and earthquakes, as well as to the hydrogeologic framework of Yucca Mountain. The Board intends to pursue this topic further with the DOE. Also, the Board believes there may be potential benefits in having an MRS facility for interim storage and waste cooling. The Board will explore the technical merits concerning the MRS facility with the DOE in the future. 


\section{Chapter 1 Introduction}

\section{Background}

The disposal of the Nation's spent nuclearr fuel and high-level waste has been studied for many years. The Nuclear Waste Policy Act of 1982 and the subsequent Nuclear Waste Policy Amendments Act (NWPAA) of 1987 provide the legislative framework under which the Department of Energy (DOE) must operate when evaluating potential sites for the geologic disposal of spent nuclear fuel and high-level waste. Additionally, the DOE must comply with regulations published by the Environmental Protection Agency (EPA) in 40 CFR 191, "Environmental Radiation Protection Standards for Management and Disposal of Spent Nuclear Fuel, High-Level and Transuranic Radioactive Wastes" and by the Nuclear Regulatory Commission (NRC) in 10 CFR 60, "Disposal of High-Level Radioactive Wastes in Geologic Repositories." The DOE also operates under its own regulation, $10 \mathrm{CFR}$ 960, "General Guidelines for the Recommendation of Sites for Nuclear Waste Repositories."

The DOE has devoted considerable resources to this program, which is managed by the Office of Civilian Radioactive Waste Management (OCRWM). Disposal of spent nuclear fuel and high-level waste in a geologic repository has never before been done anywhere in the world. Since this is a first-of-a-kind facility, extreme care must be taken to ensure that all envi-

\footnotetext{
${ }^{1}$ Commercial Nuclear Power 1989, DOE/EIA-0438, p. ix (Washington, D.C.: U.S. Department of Energy, Energy Information Administration, 1989).
}

ronmental public health standards are met during the required long life of the repository.

Yucca Mountain was designated by the NWPAA in 1987 as the sole site to be characterized for the disposal of spent nuclear fuel and high-level waste (see Figure 1). It is important to recognize that Yucca Mountain has not been chosen for a permanent disposal site or repository. Rather, it is the candidate site to be characterized to determine whether or not it meets the myriad requirements set forth in existing regulations for the long-term disposal of spent nuclear fuel and high-level waste.

The radioactive waste to be emplaced in a repository will consist primarily of spent nuclear fuel from more than 70 commercial reactor sites. It is expected that existing nuclear power plants will produce approximately 87,000 metric tons of spent nuclear fuel during their lifetime. ${ }^{1}$ A small amount of commercial and defense high-level waste from reprocessing is also expected to be emplaced in the repository.

In December 1988, the DOE published the nine-volume Site Characterization Plan, Yucca Mountain Site, Nevada Research and Development Area, Nevada, which is known as the site characterization plan or SCP. Supporting the SCP are numerous study plans that describe the procedures for gathering scientific data needed to determine whether the Yucca Mountain Site is suitable for spent nuclear fuel and high-level waste disposal. If the DOE determines the site is suitable, it must then demonstrate to the NRC that the site meets regulatory licensing criteria. 


\section{Figure 1: Description of the Yucca Mountain Site}

Yucca Mountain is located in southern Nevada about 100 miles northwest of Las Vegas within the Great Basin. The site is in Nye County, Nevada, and includes land area controlled by: (1) The Bureau of Land Management (BLM), U.S. Department of the Interior; (2) Nellis Air Force Range, U.S. Department of Defense; and (3) the Nevada Test Site, U.S. Department of Energy. The first two areas have been withdrawn from public domain and are managed by the BLM. The Nevada Test Site has been withdrawn from the public domain but is reserved for use by the DOE. Yucca Mountain is in an arid region with mountain ranges and valleys, sparse vegetation, low rainfall, and limited population. It does not have surface drainage outside the Great Basin.

Such criteria are intended to protect the health and safety of the public and to minimize environmental impacts.

\section{Brief Legislative History}

On December 21, 1987, the United States Congress enacted the NWPAA of 1987 and, in addition to taking other actions, created the Nuclear Waste Technical Review Board (NWTRB, "the Board"). President Reagan signed the bill into law on December 22, 1987.
The Nuclear Waste Policy Act of 1982 (42 U.S.C. 10101 et seq.), as amended by Public Law 100-203, E, Section 5051, established the composition of the Board, its responsibilities and authority, and its reporting requirements to the Congress and to the Secretary of Energy (see Figure 2 and Appendix A).

The Act created the Board as an independent establishment within the Executive Branch. Eleven members were to be appointed by the President of the United States from a list of no fewer than 22 persons nominated by the National Academy of Sciences. The Act specified that each nominee should be eminent in a field of

\section{Figure 2: Functions and Duties of the Nuclear Waste Technical Review Board}

The Nuclear Waste Policy Amendments Act (1987) prescribes the functions of the Board to include an evaluation of the technical and scientific validity of activities undertaken by the Secretary of Energy after the date of the enactment of the Nuclear Waste Policy Amendments Act of 1987, including:

(1) site characterization activities, and

(2) activities relating to the packaging or transportation of high-level radioactive waste or spent nuclear fuel.

The Board is to report its findings, conclusions, and recommendations at least two times per year to Congress and the Secretary. 
șcience or engineering, including environmental sciences; be selected solely on the basis of established records of distinguished service; and represent the broad range of scientific and engineering disciplines related to the activities under this law. Further, no nominee was to be an employee of the DOE; of a national laboratory under contract with the DOE; or of an entity performing high-level waste or spent nuclear fuel activities under contract with the DOE.

To better understand its role and responsibilities, the Board considered not only the mandates of the 1987 Amendments Act, but also the legislative background furnished by the Congressional Record and House Report, 100-425, Part 1 , prepared by the Committee on Interior and Insular Affairs of the U.S. House of Representatives. The House report summarizes the purpose of the Board (see Figure 3).

The Act provided for temporary and intermittent services of experts and consultants and for not more than 10 professional staff members to assist the Board in discharging its responsibilities. The intent was recorded in the following statement:

"Staff is purposely limited to ensure that the Board members themselves do the bulk of the review. The very nature of peer review

\footnotetext{
${ }^{2}$ Establishing a Nuclear Waste Policy Review Commission, Rept. 100-425, Part' 1, p. 19 (U.S. House of Representatives 100th Congress, November $5,1987)$.

${ }^{3}$ Ibid, p. 27.
}

is to require respected experts to review the work, and the intention is not to establish a large new bureaucracy to review the program." 2

The Congressional Record indicated that the House intended the Board to be an active body with an up-to-date and timely knowledge of the DOE's technical and scientific programs (see Figure 4).

The first Board report, in accordance with the Act, was to be submitted to Congress and the Secretary not later than 12 months after the enactment of the Nuclear Waste Policy Amendments Act of 1987. However, the Board members were not appointed until early 1989. This report, then, is presented 11 months after the swearing-in of the first eight members of the 11person Board.

\section{Legal and Regulatory Requirements}

As the basis for its scientific and technical evaluation, the Board inherits a very extensive ongoing program of investigations and conceptual designs undertaken by the DOE and its contractors. The DOE's work has been underway for the last two decades and has intensified since the Nuclear Waste Policy Act of 1982 and the NWPAA of 1987 . The legal and regulatory requirements developed to date set forth site, design, and licensing parameters that constrain the DOE in several areas in carrying out its assignment. Some of the major constraints

\section{Figure 3: Purpose of the Nuclear Waste Technical Review Board}

"The purpose of the Board is to provide a source of independent expert advice to DOE and the Congress on technical issues and to review DOE's efforts to implement the nuclear waste program. The Board has no authority to require the Department to implement its recommendations, but it is assumed that the Department will heed those views or clearly state its reasons for disagreeing. The Board will provide valuable assistance to the Congress in determining whether the DOE's activities have solid technical foundations."3 


\section{Figure 4: Nuclear Waste Technical Review Board Powers}

"The panel is given very strong powers to obtain information from the Department. Of course, laws such as the Privacy Act which prohibit disclosure of information in certain circumstances would apply. It should be remembered that the panel is created as an establishment in the executive branch, and that its value can only be achieved if the Secretary makes all information available on a timely basis. The provision relating to draft documents makes clear that the Secretary may not refuse to provide documents with the excuse that they are merely drafts. The Board's effectiveness is dependent upon its ability to affect actions of the Secretary while they are happening, and not just after the fact." ${ }^{4}$

placed on site characterization and repository development are as follows.

\section{A. Legal}

- Only one candidate site, Yucca Mountain in Nevada, will be characterized to determine its suitability for use as a geologic repository.

- Only one geological material will be considered as host rock for the repository-the volcanic tuff rocks of Yucca Mountain (a derivative of the preceding item since Yucca Mountain consists entirely of tuff to a depth of more than 3,000 ft).

- A monitored retrievable storage (MRS) facility, if built, cannot become operational more than 3 years before the repository becomes operational, because of the schedule linkages in the NWPAA.

\section{B. Regulatory}

- A multi-barrier approach is to be used in the design of the geologic repository. The primary barrier is the host rock, which in

\footnotetext{
${ }^{4}$ The Honorable Philip R. Sharp, U.S. House of Representatives, 100th Congress, Congressional Record, p. H11974 (December 21, 1987).
}

this case is tuff, and the secondary barrier is the engineered barrier system.

- The engineered barrier system is to provide substantially complete containment of the radionuclides for 300 to 1,000 years.

- The engineered barrier is to limit the release of the radionuclides to an annual fractional rate of $10^{-5}$ of the 1,000 -year inventory, and the host rock must ensure that the 10,000-year cumulative numerical release limits set by the EPA are not exceeded.

There are additional regulatory criteria against which the site and the design must be evaluated. These are contained in the regulations $40 \mathrm{CFR}$ 191 (currently being revised by EPA), 10 CFR 60 (NRC), and 10 CFR 960 (DOE). Since these regulatory criteria and the DOE's disposal technology are being developed concurrently, the Board will review these requirements and evaluate whether they can be met.

\section{Board and Panel Composition}

President Reagan appointed eight members to the Board on January 18, 1989, and they were sworn in at the first meeting of the full Board on 
March 7-8, 1989. (See Appendix B for the curriculum vitae of each member.) The appointments of the other three Board members are currently in various stages of the selection process.

The Chairman created five internal working panels at the first Board meeting, which was held in Washington, D.C., on March 7-8, 1989. The panels were created to address more effectively the diversity of technical and scientific topics under consideration by the Board and to reflect the different backgrounds of the members. Panels also were set up because it would be difficult to convene all Board members for the many meetings required to adequately understand, monitor, and evaluate the DOE's civilian high-level radioactive waste disposal program. ${ }^{5}$ The panels were organized around the following topics: structural geology and geoengineering; hydrogeology and geochemistry; risk and performance analysis; containers and transportation; and environment and public health.

\section{Board and Panel Protocol}

Each panel reports to the full Board at least twice a year. Included in the panel reports to the Board are the panel findings, conclusions, and recommendations based on information gathered through panel meetings, professional society meetings, and exchanges of technical information at meetings attended by panel members. Each panel report is presented to and reviewed by the full Board and eventually adopted by the Board as the work of the panel. Once a panel report is adopted by the Board, it becomes part of a broader spectrum of information used by the Board to prepare its reports. Views of the full Board on the DOE's program to characterize the

${ }^{5}$ The program is managed by the DOE Office of Civilian Radioactive Waste Management-also known as OCRWM. Unless otherwise noted, references to the Department of Energy are to OCRWM and its programs.
Yucca Mountain Site will be presented twice a year in reports to the U.S. Congress and the Secretary of Energy.

\section{Board and Panel Meetings}

The full Board met four times in 1989: March 7-8 in Washington, D.C.; June 26-28 in Las Vegas, Nevada; September 12-13 in Washington, D.C.; and December 12-13 in Denver, Colorado. During all of the meetings, the DOE and its contractors briefed the Board and responded to questions. The State of Nevada briefed the Board on its issues and concerns during the Las Vegas meeting in June 1989. At the December meeting in Denver, the Edison Electric Institute/Utility Nuclear Waste and Transportation Program and the Electric Power Research Institute briefed the Board on issues of concern to their memberships. The Board has scheduled the following meetings to date in 1990: March 2-3 in Tucson, Arizona; and April 6-7 in Las Vegas, Nevada.

The panels, comprising two to six Board members each, met a total of seven times with the DOE, representatives of other federal agencies, and DOE contractors to pursue specific topics in greater depth. Panels digested the information and presented reports to the full Board. In 1989 the panels met as follows. The Structural Geology and Geoengineering Panel met twice in Las Vegas, on April 11-12 and again on November 20-21. (The latter meeting was a technical exchange field trip to volcanic sites.) The Risk and Performance Analysis Panel met once in Washington, D.C., on May 16-17. The Containers and Transportation Panel held two meetings, one on August 21-23 in Albuquerque and the other on December 14-15 in Denver. The Environment and Public Health Panel met once in Washington, D.C., on September 14, and the Hydrogeology and Geochemistry Panel met once in Denver on December 11-12. In addition, individual Board members attended meetings of 
the DOE and the NRC, where technical information was exchanged, and some attended national and international meetings on technical issues pertaining to radioactive waste disposal.

In 1990 the following panels have met or been scheduled to meet. The Containers and Transportation Panel met January 18-19, in Pleasanton, California. The Risk and Performance Analysis Panel and the Structural Geology and Geoengineering Panel will meet March 19-20 in Denver, Colorado, and the Environment and Public Health Panel will meet April 24-26 in Las Vegas, Nevada.

\section{Recent Developments}

In the near future, the Board intends to consider issues discussed in two recently released documents that will impact the DOE's high-level waste disposal program and, consequently, the future work of the Board. The first is the Monitored Retrievable Storage (MRS) Review Commission's report, Nuclear Waste: Is There A Need For Federal Interim Storage? The report,

${ }^{6}$ Nuclear Waste: Is There a Need for Federal Interim Storage?, pp. 103105 Washington, D.C.: The Monitored Retrievable Storage Review Commission, November 1, 1989). released on November 1, 1989, contains three recommendations (see Figure 5). The second report, issued November 29, 1989, is the DOE Report to Congress on Reassessment of the Civilian Radioactive Waste Management Program (see Figure 6).

The Board intends to consider the recommendations of the MRS Review Commission and the conclusions of the Secretary of Energy as they identify and study issues pertinent to waste management and site characterization at Yucca Mountain. The Board also will review and consider the results of work performed by the State of Nevada and other groups as such reports become available.

\section{Report Format}

This report is composed of three chapters and five appendices. Chapter 2 summarizes the work of the Board's five panels. Section 1 examines the areas of Structural Geology and Geoengineering. Section 2 discusses the Hydrogeology and Geochemistry issues. Section 3 treats the work of the Risk and Performance Analysis Panel. Section 4 covers the topics of the Containers and Transportation Panel, and Section 5 is devoted

\section{Figure 5: MRS Review Commission Recommendations}

"Recommendation No. 1. Congress should authorize construction of a Federal Emergency Storage (FES) facility with a capacity limit of 2,000 metric tons of uranium (MTU).

Recommendation No. 2. Congress should authorize construction of a User-Funded Interim Storage (UFIS) facility with a capacity limit of 5,000 MTU. Such a facility would provide storage only, and would be used in addition to the Federal Emergency Storage facility proposed in Recommendation No. 1.

Recommendation No. 3. Congress should reconsider the subject of interim storage by the year 2000 to: (a) take into account uncertainties that exist today and that might be resolved or clarified within ten years, (b) consider developments that cannot be anticipated today, and (c) evaluate the experience with the two facilities recommended above." 6 


\section{Figure 6: The Secretary of Energy's Conclusions}

"The Secretary has recently completed an extensive review of the program and has concluded that it cannot be effectively executed in its present form. However, it should be possible to develop a technically sound integrated waste-management system with a repository for permanent disposal if the DOE (1) continues to implement management improvements; (2) pursues an orderly program of scientific investigations that is not driven by unrealistic scheduling demands; and (3) establishes an MRS facility with more flexible linkages to the repository to allow early acceptance of spent fuel. The program will be structured in accordance with this approach." 7

to the work of the Environment and Public Health Panel. Section 6 presents a summary of the recommendations from the previous five sections.

In Chapter 3 the Board presents what it considers to be cross-cutting issues. Some of the issues surfaced in earlier sections of the report. Others are identified for possible future study. The Board will ask the DOE, the NRC, and the EPA to brief it on selected issues during the

${ }^{7}$ Report to Congress on Reassessment of the Civilian Radioactive Waste Management Program, p. 20 (Washington, D.C.: U.S. Department of Energy, Office of Civilian Radioactive Waste Management, November 29, 1989). coming year. The views of scientists of the State of Nevada will be solicited and, as appropriate, the Board will request the views of environmental and public interest groups, other federal agencies, the nuclear industry, and professional associations, as well as state, local, and Indian tribal governments.

The appendices provide the following information: Appendix A: Summary of Law; Appendix B: Board Members Curricula Vitae; Appendix C: People Appearing Before the Board; Appendix D: Panel Members and List of Working Papers of the Board; and Appendix E: Guide to Scientific and Technical Terms. 


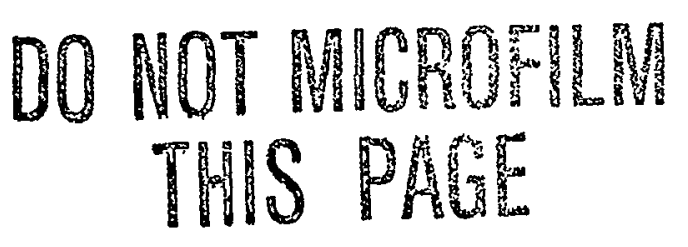




\section{Chapter 2 \\ Issues and Recommendations}

Issues of potential importance in the Department of Energy's (DOE) spent nuclear fuel and high-level waste disposal program are presented in this chapter. The issues are organized according to the work of the Nuclear Waste Technical Review Board (the Board) panels. Topics addressed by each panel are intended to reflect the major areas of scientific work that the DOE is currently performing, or will need to undertake, to characterize the site.

Structural geology refers to the natural processes of volcanism, faulting, and earthquakes and related rock deformation. If it can be determined that volcanic activity is reasonably likely to occur within a repository or close enough to disrupt the site, then the site would be disqualified. Similarly, if scientists predict that faulting is reasonably likely to occur within a repository and would significantly disrupt it, the repository site would be disqualified. Geoengineering refers to the design, construction, and performance of the exploratory shaft facilities and underground openings at the repository.

Hydrogeology at the Yucca Mountain Site involves the study of fluid transport through the rock matrix and fractures. Hydrogeologists are concerned with possible engineering problems in repository construction, operation, and closure and with the rate of movement of groundwater that might transport radionuclides (atoms that are radioactive) from the repository to the accessible environment. Geochemistry as applied to the Yucca Mountain Site is concerned primarily with the potential migration of radionuclides to the accessible environment. Geochemists, therefore, are studying the chemical and physical properties of the minerals, rocks, and waters that might retard the migration of radionuclides from a repository.

Risk and performance analysis refers to the need to analyze those factors that could influence the long-term performance of the Yucca Mountain Site. Such analysis covers all areas and provides an integration of each scientific and technical aspect into a picture of the entire characterization effort. For example, if planned studies of volcanism do not provide information needed to determine the suitability of the Yucca Mountain Site, changes to the study plan should be made.

Issues addressed in the context of containers and transportation refer to the study of the receptacles that could be used for disposal of spent nuclear fuel and high-level waste at the repository, as well as the transportation issues inherent in moving the spent nuclear fuel from more than 70 commercial nuclear reactor sites nationwide and the high-level waste from DOE defense facilities to a disposal site.

Environmental issues refer to the impact that site characterization activities and development and operation of the repository will have on the air, water, cultural, and biological resources at the site for thousands of years to come. Public health issues involve potential effects on human health of repository development and operations, both during the period of development and operation and in the period after closure of the repository. The public health and environmental consequences of the transportation of high-level 
waste from point of origin to the repository are also of concern.

The following information summarizes the first 11 months of work by the Board. Where the Board's investigation and research have progressed sufficiently, recommendations are included. Some of the issues raised here, however, have not yet been examined completely enough by the Board to warrant recommendations. The Board intends to explore such issues further.
Recommendations made in this chapter are intended to aid the DOE in its efforts to improve technical work being conducted at the site, to assist the DOE in its overall plan to study the site so as to make possible early identification of any disqualifying site characteristic, and to identify areas for possible improvement in DOE's transportation program. The Board also identifies issues for future inquiry that may eventually require legislative or regulatory changes in the Nation's program to site a permanent repository.

\section{Section 1: Structural Geology and Geoengineering ${ }^{1}$}

A major task of the Board is the review of the DOE program for evaluating the proposed Yucca Mountain Site. The DOE must determine not only if a suitable repository can be developed at Yucca Mountain, but also whether future repository performance at the site can meet the regulatory requirements promulgated by the Environmental Protection Agency (EPA) and the Nuclear Regulatory Commission (NRC). The site characterization program defined by the DOE consists of a series of studies and site investigations to evaluate the capability of the site to meet these requirements.

Structural geology and geoengineering aspects of the proposed site characterization program are included in the DOE's site characterization plan (SCP). Two dominant activities included in the SCP and focused on by the Board are: the study of tectonic features and processes (volcanism, seismicity, and faulting); and the evaluation of the Yucca Mountain geologic block by means of surface and subsurface exploration including the use of exploratory shafts. Issues relating to these

\footnotetext{
${ }^{1}$ This section is based on the September report to the Board by the Structural Geology and Geoengineering Panel plus subsequent events. Since the report, the Board has been in contact with the DOE; members and staff have attended DOE/NRC technical exchanges on tectonic issues; the Board sponsored a 2-day technical exchange field trip to pertinent volcanic cones near Yucca Mountain and adjacent areas. Finally, the section reflects discussions among Board members.
}

activities are addressed in the following sections. These issues are of paramount importance because they will determine in part the outcome of the suitability of the Yucca Mountain Site

\section{Tectonic Features and Processes}

\section{A. Issues of Concern}

As a result of research activities to date, the Board has identified several broad areas for further extensive inquiry. These are volcanism, seismicity and faulting, and licensing standards and criteria involving geologic issues.

\section{Volcanism}

The probability of disruption of the Yucca Mountain Site by volcanic intrusion has been investigated and debated extensively. The Board, therefore, selected this issue for detailed examination in its initial year. On November 20-21, 1989, the Structural Geology and Geoengineering Panel had a tour of volcanoes in the Yucca Mountain vicinity and of a geologically similar volcanic region in eastern California. Also, a detailed review of DOE's research program on volcanism with DOE's contractors and other experts in volcanism was conducted. 
Yucca Mountain lies within a region that has experienced volcanism during the Miocene epoch to possibly as recently as the Holocene epoch (ranging from the present until 12,000 years ago). During the Miocene and Pliocene epochs (24 million to 2 million years ago), major caldera explosions and eruptions of ash flows occurred in the Yucca Mountain region, and it is, in fact, these ash flows (tuffs) into which the proposed repository will be emplaced. Major caldera explosions have not occurred in southern Nevada for more than 7 million years, and this type of eruption is not regarded as a significant hazard to the repository. The focus of concern over volcanism is the potential for new or renewed volcanic eruptions of lesser magnitude and of a less explosive type in the immediate area of Yucca Mountain. There are three younger volcanic lineaments or zones nearby, each with a number of small cones and, in the case of the Lathrop Wells Center, a single young cone, all of which have formed in the past 3.7 million years. Some activity may have occurred within the past 10,000 years.

Critical questions about the calculations that determine the probability of disruption of the site due to a volcanic intrusion include the following.

- What are the boundaries of the geographic area where future volcanic centers could form?

- Is there an equal probability anywhere within the Yucca Mountain Site of formation of a new volcanic center or an occurrence of a new eruption?

- What time interval between eruptions ought to be included in calculations to determine the probability of a volcanic eruption?

Although seriously delayed by failure of the State of Nevada to grant permits for surface exploration, field work by several groups is continuing. Of particular significance are continuing efforts to obtain radiometric age dates on rock samples from the various volcanic centers as well as continuing development of soil chronologic stratigraphy (i.e., ages of formation and depth of soils after volcanic eruption). Data from both efforts are essential in providing adequate answers to the above questions. The Board finds that the DOE and its contractors, as well as the consultants to the State of Nevada, are pursuing a well-conceived volcanism study program.

\section{Seismicity and Faulting}

Concern exists about the possible effects on the repository and surface facilities of future seismicity (ground motion) and of fault displacement (surface or near-surface ground rupture). Two issues may be raised in looking at the period of time before the repository is permanently sealed (i.e., during the preclosure phase):

- possible damage to the surface facilities by ground motion (vibrations) associated with a large nearby earthquake, and

- possible damage to the surface facilities by fault displacement at the surface.

Two issues also emerge in reviewing the period of time after the repository is permanently sealed (i.e., during the postclosure phase):

- possible failure of the canisters by fault displacement within the repository geologic block, and

- possible change in groundwater depth and flow pattern because of either ground motion or fault displacement associated with a nearby earthquake.

The Board intends to ask the DOE for a technical and scientific briefing on these matters 
during early 1990. It would appear that some issues may be less important than others.

\section{Licensing Standards and Criteria Involving Geologic Issues}

Licensing standards and criteria for the repository, as promulgated by the EPA and the NRC, must be adequately conservative on the side of safety and protection of the accessible environment. However, the standard should not impose restrictions that would foreclose at the outset a candidate site subsequently shown to be suitable based on sound scientific considerations. In this light, the Board has been working with personnel from the EPA, the NRC, and the DOE and has participated in recent technical discussions between the DOE and the NRC concerning various geologic issues. The Board expects to continue these activities in 1990 .

\section{B. Recommendations}

The Board is at the information-gathering stage on tectonic features and processes and will be making recommendations on these issues in upcoming reports.

\section{Geologic Block Evaluation: Exploratory Shaft Facility}

Because of the DOE's early 1989 plans to proceed as quickly as possible with the construction of two exploratory shafts as part of the Yucca Mountain Site characterization program, the Board gave much of its attention to that subject and requested meetings with the DOE to gather data, particularly with regard to potential use of modern mechanical excavation techniques, employing tunnel and shaft-boring machines.

The DOE's current plan is to sink two exploratory shafts at the proposed site. The purpose of sinking the shafts is to permit geologic mapping and acquisition of data needed for site characterization. It is important to recognize that construction of either a shaft or a tunnel is not a commitment to construction of a repository. The sole purpose of constructing a shaft or tunnel is to obtain data to determine if the repository site is acceptable. In examining the DOE's program for developing the exploratory shaft facility, the Board has identified the following issues of concern.

\section{A. Issues of Concern}

\section{Shaft Construction}

The DOE's program contemplated the excavation of two exploratory shafts, each about 1,100 feet deep, using conventional drill-andblast techniques. These techniques can cause disturbance to the rock walls in two ways: (1) by introducing water into the unsaturated rock from the blast-hole drilling, and (2) by creating new fractures and opening up existing natural fractures by the dynamic blasting forces. By contrast, mechanical excavation techniques would reduce the disturbance to the rock walls of the shafts and also would provide the potential for faster and more economical excavation. The less disturbed rock walls of the shafts also would make the conduct and interpretation of in-situ testing more reliable.

\section{Exploration of the Ghost Dance Fault}

The initial study plans of the DOE call for a number of exploratory drifts (tunnels) to be excavated from the bottom of the shafts to explore for specific geologic features. One of these is to cut the Ghost Dance Fault, which crosses the site in a north-south direction. The Board believes that this potentially important fault should be crossed at least twice by exploratory drifts, so that the fault zone may be inspected and characterized in different areas. One of these crossings should be made farther to the south, where the fault displacement is believed to be larger than in the vicinity of the exploratory shafts. 


\section{An East-West Exploratory Drift}

The Board believes that an additional exploratory drift should be driven over and above those proposed in the SCP. This drift would run east-west across the middle of the Yucca Mountain block and would facilitate the detection of any unknown north-south trending faults that might exist. Also, the additional drift would offer the opportunity to inspect and characterize a larger extent of the candidate repository host rock (welded tuff) closer to the center of the site and away from the shafts.

\section{An Inclined Ramp into the East Side of the Yucca Mountain Block}

Consideration should be given to replacing one of the two exploratory shafts with an inclined tunnel (or ramp) driven from the surface into the east side of the Yucca Mountain geologic block. Such a ramp would cross a number of the known faults that occur between the surface facilities and the repository area in Yucca Mountain. The ramp would allow the faults to be inspected at some depth below the surface where they can be characterized better than at the surface. The ramp also would intersect most of the tuff units of interest and would allow for short exploratory rooms or drifts to be excavated at any point of special interest for detailed mapping or testing.

\section{Geologic Mapping of Shafts and Tunnels}

The DOE and its contractors have emphasized the need to carefully map the shaft and tunnél walls, particularly the natural fractures or joints that occur in the different geologic units. The Board agrees that such mapping is important so that indexing of the fractures can be done for comparison with other geological units and with the same unit at other locations. Units can also be correlated with mechanical properties, such as permeability, deformability, and strength.

Mapping of the shaft or tunnel walls that have. been bored, rather than blasted, should provide the most reliable data because of the less dis- turbed conditions. Before mapping the rock, the surfaces must be cleaned of dust and perhaps stained by brushing or spraying on a liquid to enhance the recognition of the finer joints.

\section{Exploration of the Softer Tuff Units}

Within the 1,100-foot-thick tuff units that occur between the repository level and the surface are a number of interbeds of softer, tuff units, which are much less fractured and thereby less permeable than the harder welded tuff units. These softer, less fractured units are important in impeding downward flow of surface infiltration. Also, below the repository level, the thick Calico Hills formation is a similar, softer, and less fractured tuff that will provide the main retardation of downward flow from the repository level to the deep groundwater table.

The DOE exploratory program should include both borings and penetration by shafts, ramps, or tunnels of these softer, less permeable units, so that inspection, mapping, and testing can be conducted. The outcome of work on these units is critical to site characterization.

\section{B. Recommendations and Future Plans}

The Board is pleased to note that the DOE has received its recommendations favorably and has initiated detailed studies to see how mechanically excavated shafts and drifts can best fit into the exploratory shaft facility configuration. The DOE also will investigate the Board's recommendation of replacing one of the shafts with a ramp excavated into the east side of the Yucca Mountain geologic block. The Board, therefore, makes the following ongoing recommendations to the DOE.

1. Maximize the use of the most modern mechanical excavation techniques in the recently initiated studies of alternative shaft and tunnel construction methods. 
2. Cross the Ghost Dance Fault with an exploratory drift at more than one location.

3. Definitively plan an additional early exploratory drift in an east-west direction across the Yucca Mountain geologic block to reduce uncertainties and to increase confidence as early as possible that potentially disqualifying geologic features do or do not occur.

4. Continue the studies for incorporating an exploratory ramp entering the Yucca Mountain geologic block from the east.

5. Include in the DOE exploratory program ample penetration of the softer, less permeable tuff units by borings, shafts, ramps, or tunnels so that inspection, mapping, and testing of these critical units can be conducted, both above and below the repository level.
6. Develop innovative ways of coordinating and sequencing the excavation and scientific testing so that both programs can be executed in a timely manner without sacrificing the scientific validity of the testing.

The Board will continue in its efforts to implement these recommendations through close contact with the DOE.

The Board's future plans in the area of geoengineering are to study the planned rock mechanics testing and to inspect the area of recent in-situ testing in the welded tuff at the G-tunnel at the Nevada Test Site. In addition, a meeting is being planned with the DOE and the DOE contractors responsible for developing alternative exploratory facility configurations and the preliminary design of the proposed repository.

\section{Section 2: Hydrogeology and Geochemistry ${ }^{2}$}

The hydrogeological and geochemical activities of the Board complement its structural geology and geoengineering activities in providing a comprehensive assessment of the DOE program to characterize the Yucca Mountain Site.

The hydrogeological and geochemical efforts have concentrated on two key aspects of the site characterization program: (1) the modeling and prediction of groundwater travel time (GWTT) within the Yucca Mountain geologic block, and (2) the radionuclide sorption characteristics of the various tuffs that make up the Yucca Moun-

\footnotetext{
${ }^{2}$ This section is based on the January 1990 report to the Board by the Hydrogeology and Geochemistry Panel. The report reflects 10 months of work including technical meetings and conversations with representatives and consultants from the DOE, the U.S. Geological Survey, and the State of Nevada.
}

tain geologic block. The ability of the proposed site to provide a geologic barrier capable of meeting EPA and NRC regulations on the longterm movement of radionuclides to the accessible environment is controlled by these two aspects. If fracture flow exists within the unsaturated tuffs above and below the repository horizon, allowing unacceptably rapid groundwater travel times, the Yucca Mountain block could be found unacceptable. Zeolites and other potentially sorbing minerals in the tuffs may, in conjunction with long GWTTs, greatly retard radionuclide migration. These site characteristics are key factors in meeting the requisite EPA and NRC safety requirements. Issues of concern and recommendations, which were adopted by the Board in its deliberations over this first reporting period, are presented in the following paragraphs. 


\section{Issues of Concern}

\section{A. Recharge to the Unsaturated Zone}

A determination of the rate and distribution of precipitation on and around Yucca Mountain and the accompanying recharge of moisture into the unsaturated tuffs are important parts of the DOE site characterization program. The DOE has an ongoing research program that examines infiltration of precipitation via bedrock outcrops and alluvium and infiltration and subsurface movement of water during storms. The DOE researchers have found that water enters fractures and causes saturated zones to develop in bedrock on some valley slopes, as evidenced by the behavior of water in a specific borehole at Yucca Mountain (neutron borehole N2). The researchers conclude that water is stored in the alluvium and that percolation is most likely when storms closely succeed one another.

The Board believes that infiltration of snowmelt and rainfall into surficial and suballuvial fractures should be examined in detail, using neutron probe data in combination with isotope geochemistry techniques, such as water analysis for ${ }^{3} \mathrm{H}$ and ${ }^{36} \mathrm{Cl}$, to trace and date subsurface water. The Board believes that the program to better understand recharge to the unsaturated zone at Yucca Mountain is well planned but should be expanded and accelerated.

\section{B. Measuring Fluid Flow Potential}

The DOE researchers have made measurements of soil moisture and soil moisture tension in the unsaturated zone at Yucca Mountain. Results of baseline measurements (borehole UZ1) and analog studies (G-tunnel) suggest that such measurements in rock bodies are feasible and that equilibration times are not excessive. However, instruments are to be calibrated in the laboratory and not in the field, an approach that departs from normal procedure. The results of laboratory calibration should be compared to calibration performed at Yucca Mountain.

\section{Hydrogeologic Models}

The Board is concerned that the DOE program may place the ultimate burden of proof of site acceptability as defined by GWTTs on model predictions in lieu of site characterization data that may be difficult to obtain. The DOE has assured the Board that this is not the case and has stated that the "purpose of modeling is to identify the circumstances under which the site may fail to meet the regulatory criteria"; that "modeling is a process, not a product"; and "modeling tests the consequences of the analyst's assumptions."

The Board believes that model validation methodology should be based on developing an assurance that a predictive model provides an adequate representation of the system that the model is intended to simulate, using independent field data acquired from the system under study. In addition, model validation should not be a final step in the site characterization process. Model validation should be checked each time new applicable hydrogeologic, geochemical, or other data or test results are obtained from the site characterization program. Model validation should be an iterative process, where predicted results are compared to measured data at every opportunity in the process, and the model is further refined, if necessary, as new data become available.

The DOE has developed a comprehensive list of assumptions upon which the hydrogeologic modeling at Yucca Mountain is based and has made the following two observations. First, short liquid-phase travel times are sensitive to the existence of continuous fracture pathways; second, if continuous pathways exist, travel times of less than 1,000 years may be generated. To meet the requirements of 10 CFR 60, it will be necessary to evaluate all travel times, particularly the fastest ones, not just the mean times. The 
Board is pleased that the DOE has taken this position with regard to GWTT. If this position is maintained, it will be more difficult to misuse stochastic GWTT model outputs.

\section{Moisture Movement in the Unsaturated Zone}

Measurements have shown that some fracture flow occurs in the unsaturated zone at Yucca Mountain. The ${ }^{3} \mathrm{H}$ and ${ }^{36} \mathrm{Cl}$ data from relatively deep holes indicate that modern (post-1950) recharge has penetrated the rock to depths of at least 400-500 feet, but the hole where these depths were found was at the crest of Yucca Mountain and closely adjacent to the bluff edge. Possible lateral, rather than vertical, flows can thus not be ruled out. Water penetration depth is not uniform across the mountain, and similar penetration does not occur in all boreholes. Nevertheless, data indicate that the rocks are not as impermeable to water penetration as initially thought. In fact, on the basis of these findings it appears that the main line of geologic defense against rapid downward movement of water through a repository at Yucca Mountain may be the Calico Hills unit beneath the proposed repository.

As a related concern, the Board notes that on the basis of a limited number of laboratory measurements, it appears that the Calico Hills unit has a permeability ranging from $10^{-10}$ to $10^{-5} \mathrm{~cm} /$ second and a porosity range of from 14 to 46 percent. This wide range of values suggests that the Calico Hills unit also may be fractured. To help resolve this critical question, further sampling and analyses of deep unsaturated zone waters for their ${ }^{3} \mathrm{H}$ and ${ }^{36} \mathrm{Cl}$ contents should be performed as soon as possible. The essential need for detailed information on the hydraulic properties of the Calico Hills unit is also a strong argument for penetrating that for-

${ }^{3}$ J.R. Smyth, "Zeolite Stability Constraints on Radioactive Waste Isolation in Zeolite-Bearing Volcanic Rocks," Journal of Geology, vol. 90, pp. 195201 (1982). mation 'with surface borings and with the exploratory shaft facility.

\section{E. Thermal Stability of Zeolites}

Conflicting views exist as to the consequences to repository performance of the dehydration of the zeolite minerals present in tuffs due to elevated temperatures adjacent to the waste package. Dr. J.R. Smyth has stated that because of the thermal instability of zeolites, zeolitebearing horizons must be kept saturated and below $85^{\circ} \mathrm{C}$ to retain the radionuclide sorption characteristics of the zeolites. ${ }^{3}$ This would limit the temperature rise in rocks $20-50$ meters from a repository to about $50^{\circ} \mathrm{C}$. A gross loading of as little as $75 \mathrm{kw} /$ acre for spent fuel may result in temperatures in excess of $110^{\circ} \mathrm{C}$. This position has not been accepted by the DOE mineralogists.

Evidence discussed by the DOE suggests that dehydrated zeolites, when rehydrated, regain their radionuclide adsorptive potential. However, there is still evidence of a permanent volume increase of perhaps 12 percent upon rehydration. The Board believes that this issue is not totally resolved and recommends that it be studied further by the DOE.

\section{F. The Applicability of Laboratory-Measured $K_{d}$ (sorption) Values to the Prediction of Radionuclide Transport at Yucca Mountain}

Numerous laboratory measurements of radionuclide uptake or sorption from solution by geological materials such as granite, basalt, and tuff have been performed since the early 1980 s by the DOE and its contractors. Unfortunately, most of these data cannot be used directly to predict the mobility of radionuclides at Yucca Mountain for three reasons. First, almost without exception, the conditions chosen for the sorption experiments differ significantly from both the preclosure and postclosure conditions expected at Yucca Mountain. Most such experi- 
ments were, in fact, performed not on tuff, but on the rocks at other potential repository sites. Second, the experimental conditions used in the laboratory were often either inexactly or incompletely documented and cannot be duplicated or their results fully understood. Third, little or no effort was made to design the experiments to account for the fundamental factors controlling radionuclide sorption; i.e., how and why sorption varies with expected changes in a dozen or more key properties of the sorbing solid and the aqueous phase.

Some important differences between the experimental conditions selected for these early sorption experiments and the conditions at Yucca Mountain generally have included the following.

- The experiments were performed using crushed tuff rather than intact tuff samples.

- Saturated batch experiments were run, whereas the tuff at Yucca Mountain-is generally unsaturated.

- Sorption was studied at ambient rather than elevated temperatures and at constant temperatures instead of using temperature gradients expected near a repository.

- Until recently, initial solution compositions were not computer modeled to prove that the solutions were undersaturated with respect to appropriate radionuclide minerals. (In early sorption studies, initial radionuclide concentrations were often too high, and sorption included a combination of true radionuclide adsorption and precipitation in solids, thereby making the results difficult to interpret.)

- It has been assumed incorrectly that groundwaters from the saturated zone near Yucca Mountain (from well J-13, for example) are compositionally representative of unsaturated zone groundwater from
Yucca Mountain. (The Board believes this assumption is invalid. According to analyses by the U.S. Geological Survey, waters in the unsaturated zone generally have a significantly higher concentration of dissolved solids than does the groundwater from the saturated zone.)

The Board believes that results obtained from early rock sorption experiments cannot be used for performance assessment unless it can be shown that the results represent true adsorption, without concurrent precipitation of solids and that they have been obtained for conditions that can be expected at Yucca Mountain. Furthermore, it can generally not be proven that the amount of adsorption measured in past experiments represents a maximum or minimum (conservative) or is only within the range of possible values to be expected at Yucca Mountain.

\section{G. Suggested Approaches to the Study of Radionuclide Adsorption by Tuff}

At least two approaches are available to study adsorption by unsaturated tuffs. One approach usès an ultracentrifuge, such as being used by Dr. J.L. Conca at the Pacific Northwest Laboratories. A second approach uses columns that contain packed, crushed tuff (properly crushed and pre-treated), or intact tuff cores, in columns of a design commercially available. This apparatus was designed by Dr. Peter Wierenga, soil physicist at the University of Arizona. The apparatus permits a comparison of radionuclide adsorption from the same solution onto a given tuff for both saturated and unsaturated flow conditions. A tracer such as ${ }^{3} \mathrm{H}$, bromide, and/or ${ }^{18} \mathrm{O}$ or deuterium may be introduced along with the radionuclide of interest, to define the saturated and unsaturated hydraulic properties of the column. Comparison of the results obtained through such saturated and unsaturated column tests with earlier adsorption results obtained only in comparable saturated batch or column tests 
might allow those earlier saturated system results to be quantitatively interpreted.

The Board feels more work is needed to establish which minerals in the tuff are most sorbent. This work should include determining those geologic conditions under which maximum and minimum radionuclides are likely to occur. This effort should involve the detailed study of radionuclide adsorption by the most-strongly adsorbing minerals. Much published work already is available in this area for radionuclides, including those of $\mathrm{U}, \mathrm{Th}, \mathrm{Ra}, \mathrm{Pu}, \mathrm{Sr}$, and $\mathrm{Cs}$, and, for example, onto strongly adsorbing minerals, including amorphous silica, kaolinite, smectite, and ferric oxyhydroxides. Adsorption has been studied as a function of water/mineral ratio, mineral surface area, surface charge and potential, solution $\mathrm{pH}$, ionic strength, and competing and complexing ions. Based on such experiments, the fundamental controls on adsorption of these elements are reasonably well understood.

A simplifying approach to take, based on these results, is to assume initially that the adsorption of a particular radionuclide by a given tuff is controlled only by the strongly adsorbing minerals in the rock, and that the other tuff minerals can be ignored. A surface complexation-modeling approach to the adsorption data is probably the most useful way to identify the major controls and limits on adsorption of a particular radionuclide by a given mineral.

Attempts have been made to estimate whole rock adsorption by proportionally summing the adsorption measured separately in the same solution by each mineral in the rock. This simple adsorption additivity approach has not yet been applied successfully to adsorption by multimineralic rocks such as tuffs; however, the Board suggests that efforts to do so should be continued.

The Board suggests that an important question to answer is does the amount of adsorption measured for a particular radionuclide represent a conservative result for the expected environ- ment at Yucca Mountain and, if so, is the extent of adsorption consistent with regulatory requirements? An understanding of the adsorption of a particular radionuclide by unsaturated tuff may not be necessary to answer this question. The Board believes that a sufficient understanding is one that allows us to argue with confidence that a particular sorption value is truly conservative. Such an understanding cannot be obtained until a greater effort is made to design experiments to study conditions comparable to the range of conditions expected at Yucca Mountain and until a better understanding is obtained of the fundamental processes that control radionuclide adsorption by unsaturated tuffs.

\section{Conclusions and Recommendations}

1. The Board believes that DOE research on the rate and distribution of recharge to the unsaturated zone within the Yucca Mountain geologic block is well conceived and well planned. The Board recommends that the DOE expand and accelerate studies of snowmelt and rainfall infiltration into alluvium and near-surface fractures.

2. The Board recommends that the DOE continue the sampling and analysis of ${ }^{3} \mathrm{H}$ and ${ }^{36} \mathrm{Cl}$ isotopes to gain a better understanding of the surface features that control this deep penetration of recharge. Recent data for these isotopes in deep boreholes suggest that flow occurs in fractures in the unsaturated zone, at least to some extent, resulting in rather deep (400-500 ft) penetration of modern recharge, either from vertical or lateral directions.

3. The Board recommends that the DOE approach hydrogeologic modeling in the program in a more systematic fashion. All predictive hydrogeologic models should be validated each time new pertinent field data 
are made available. Validation should be a continuous iterative process. The relationship between the use of deterministic and stochastic models should be clarified. Stochastic models of the Yucca Mountain Site are currently based on deterministic models; which in turn assume a layered conceptual model. It is impossible to avoid basing stochastic models on deterministic models, but it is not necessary that deterministic models of 'Yucca Mountain be layered. To date, the assumption of layered groundwater flow behavior is based on geologic, not hydrogeologic, evidence.

4. The Board recommends that the DOE penetrate and explore the Calico Hills unit with surface borings and with the exploratory shaft facility. Given that the Calico Hills unit is considered the principal hydrogeologic barrier in the unsaturated zone, the hydrogeologic properties of the Calico Hills unit must be understood thoroughly. This is particularly critical given the apparent deep penetration of post-1950 recharge in the unsaturated zone that is evident from the isotopic analyses discussed under Recommendation 2 above. The wide range of porosities and permeabilities reported for the Calico Hills unit suggests that this unit may also be fractured.

5. Available radionuclide adsorption data are largely inapplicable to Yucca Mountain. To prove that adsorption has been measured conservatively, experiments at least must bracket the range of conditions that can be expected at Yucca Mountain. The Board recommends that the DOE study adsorption in unsaturated tuffs, over the range of temperatures and variable conditions of $\mathrm{pH}$, ionic strength, and competing and complexing aqueous ionic species concentrations expected at the site. Much can be learned about the processes that limit and define adsorption by performing detailed studies using the most strongly adsorbing minerals present in the tuff.

6. The Board recommends that the DOE organize a radionuclide adsorption workshop to be attended by the DOE and its contractors involved in the measurement and modeling of such adsorption. The workshop would have two general purposes, (a) to determine the applicability of available radionuclide adsorption data on tuff and models for predicting such adsorption under existing and postclosure conditions at Yucca Mountain, and (b) to establish what additional radionuclide adsorption research and model development are needed. Such research and model development should attempt to demonstrate that quantitative scientifically defensible predictions of radionuclide adsorption at Yucca' Mountain are possible and show how such measured and predicted adsorption relates to compliance with the radionuclide release rate criteria set forth in 40 CFR 191. 


\section{Section 3: Risk and Performance Analysis ${ }^{4}$}

The Board has the responsibility to address the broad questions - what are the risks from the proposed repository at the Yucca Mountain Site, and how should these risks be evaluated? It is the Board's intent to approach these questions by integrating or synthesizing the many relevant issues and scientific disciplines. Defined here, "risk" means the potential likelihood and severity of adverse impacts caused by site characterization activities, or by future siting of a repository at Yucca Mountain.

"Performance assessment" is defined by the DOE as the

- process of evaluating the repository system, subsystem, and component performance,

- demonstration of compliance with numerical criteria in the regulations, and

- support for repository development, including site characterization and design.

The DOE has stressed that performance assessment is multi-faceted, that it involves "data evaluation, model development, scenario development, [computer] code development, probabilistic risk assessment, expert judgment, and you name it." 5 The DOE has described its site characterization program as "meeting identified information needs," to improve understanding and

\footnotetext{
${ }^{4}$ The Board has adopted a report from the Risk and Performance Analysis Panel based on the first meeting of the Panel on May 16-17, 1989. This section is based upon this report and additional information gathered by the Board.

${ }^{5}$ Dr. Donald H. Alexander, Grants Chief, Regulatory Compliance Branch, OCRWM, U.S. Department of Energy, Public Transcript of the Nuclear Waste Technical Review Board's Risk and Performance Analysis Panel Meeting of May 16, 1989, p. 23.

${ }^{6}$ Dr. Jean L. Younker, Senior Staff Geologist, Science Applications International Corporation, Public Transcript of the Nuclear Waste Technical Review Board's Risk and Performance Analysis Panel Meeting of May 17, 1989, p. 48.
}

reduce uncertainty with regard to the processes that can have an adverse effect on containment and isolation of the waste materials. There are many such processes affecting the natural geological system, the engineered barrier system, and in some cases, both. Most of these processes are both complex and imperfectly understood.

Performance assessments identify the information needs for site characterization. The questions are: When do we determine the need is met, and how much information is enough? The DOE uses the term "performance allocation" to describe its information gathering strategy: "...You have to figure out what it is you are going to rely upon...what are the important features of the site and of the engineered system that you are going to rely upon for the fundamental performance?" 6 Given the uncertainties and complexities in the processes affecting waste isolation and containment, performance allocation is a difficult management task.

The data base for performance assessment at Yucca Mountain has evolved relatively little since it was used for the 1986 environmental assessments. The DOE's main effort has been planning the site characterization process. Some methodology development and critical reviews of past work have identified new needs and opportunities for analysis. But the momentum in the DOE program has suffered from

- continuing delays in initiating additional subsurface exploration activities planned for the site, and

- the absence of the main support contract because procurement has been in process for $21 / 2$ years.

While the site characterization plan sets forth a general strategy, many details of the integration needed for risk and performance analysis logi- 
cally fall under this support contract. Clearly, the rate of the DOE's progress will depend on how quickly these two problems can be resolved.

The Board must evaluate the DOE's activities on site characterization, and, to carry out this assignment, the Board intends to address the DOE's plans, its strategy for performance allocation, and the relation between the information available on the repository and the overall risk. To date, the Board has identified the following risk and performance assessment issues, which could prove important in evaluating the Yucca Mountain Site.

\section{Issues of Concern}

\section{A. Performance Allocation and Assessment}

Performance allocation is clearly a difficult problem, given the diversity of issues and the abundance of scientific uncertainties, particularly in the postclosure time period. The site characterization and study plans provide a useful baseline for refinement, and the DOE will be evaluating the comments from the NRC, the State of Nevada, and others-a process from which the Board expects to learn much. The main concern, however, is generic. How flexible is the DOE's process for incorporating the results of new data as they are obtained and for adapting its very extensive site characterization plans if uncertainty is resolved in unexpected ways? What are the most important parameters and the key assumptions in modeling? What may be learned early in the site characterization process that might cause today's judgments about parameters and model assumptions to change significantly?

While the Board endorses the DOE's approach of using sensitivity analysis to investigate the importance of individual parameters and assumptions, it is interested in finding out why more investigation of this type has not been done in support of DOE program planning. The
Board looks forward to learning more about the DOE's plans and progress in applying performance allocation-from the DOE and its contractors and from other interested parties.

\section{B. Methodology for Assessing Expert Judgment}

It is evident that many crucial issues in performance assessment cannot be addressed through data collection. Therefore, the DOE may need to use modeling techniques and the collective judgment of technical experts to assess performance for some issues. Examples of issues that may need such treatment include potential climate alteration, human intrusion, and projections of future volcanism and fault displacement. The validity of models and credibility of expert judgment are likely to become important and potentially controversial issues in licensing of and in public acceptance of the repository should it be licensed. While the Board endorses involving technical experts in addition to the DOE and its contractors, it is concerned about the DOE's peer review process, since detailed plans for the process, as well as for model validation and elicitation of expert judgment, have not yet been presented.

\section{Overall Characterization of Risk}

The Board members are charged by legislation to advise the Congress and Secretary of Energy regarding site characterization and the safety of the repository proposed for Yucca Mountain. As such, the Board is obliged to look at the "big picture"-the risks a repository at this site poses -and consider these risks using scientific judgment. The Board must also evaluate how well these risks have been characterized and the extent to which critical issues have been adequately investigated. To do this, the Board must consider the DOE program, as well as NRC and EPA activities, in establishing site acceptability criteria. 
There are areas where the criteria may be ambiguous and subject to differing interpretations. Potential problems relating to the consistency of these criteria deserve investigation. Therefore, the Board plans to work with the DOE, the NRC, the EPA, and other concerned parties to clarify the "big-picture" issue of how to characterize and evaluate the criteria so that the reasons for deciding on the Yucca Mountain Site can be understood in layperson's language. Not doing so could result in the appearance that the decision to license Yucca Mountain hinges on detailed technical regulatory requirements, the basis of which is apparent only to the few specialists who have been involved in high-level nuclear waste issues for many years. Such a decision process would be less understandable and, therefore, less acceptable to the American people.

\section{Recommendations and Future Plans}

The Board recommends that the DOE proceed as rapidly as possible to: (1) develop needed methodology for performance assessment; and (2) carry out preliminary implementation of performance assessment for the Yucca Mountain Site with the scientific information and data available.

While a major application of performance assessment is for the licensing application to be submitted to the NRC, the DOE should not delay performance assessment until data from the planned site characterization activities to support the license application become available. Rather, the DOE should move vigorously to develop its performance assessment methodology and to implement performance assessment as a guide for site characterization management, licensing, and repository design activities. Early application of performance assessment should identify critical problem areas and facilitate timely pro- gram planning, data-gathering activities, and repository design revisions that deal with these critical problem areas. It may also demonstrate the suitability - or unsuitability - of the Yucca Mountain Site at an earlier date. As additional scientific data become available, the performance assessment should be revised accordingly. Assuming that the site is found to be suitable, the performance assessment should, over time, produce data that can be used in a licensing application.

Given the state of progress on performance assessment and the broader issues of risk analysis, the Board expects to learn a great deal in the coming year about these issues. The Board will invite the DOE, the State of Nevada, and other interested parties to communicate their views at the next meeting of the Risk and Performance Analysis Panel, scheduled for March 19-20, 1990 , in Las Vegas, and in subsequent meetings.

One crucial issue is the relation of performance to the thermal output of the nuclear fuel, which depends on the age of the fuel, and on the loading and spacing of waste containers. Thermal loading may have important impacts on the performance of the proposed Yucca Mountain repository. Aging of spent fuel may also be important in determining the need for a monitored retrievable storage (MRS) facility. The Board will focus on the issue of thermal loading and its relation to performance assessment during this year.

Other nations' approaches and experience to date on risk and performance analysis may be instructive. In October 1989 the Chairperson of the Risk and Performance Analysis Panel represented the Board at an international waste management meeting in Europe, where many papers on risk and performance analysis were presented. Performance assessment and risk analysis will be a major focus of the Board's work during the upcoming year. 


\section{Section 4: Containers and Transportation ${ }^{7}$}

The Board has identified three issues of concern relating to the transportation of spent fuel: system safety, human factors, and risk assessment and management. These issues, along with the Board's recommendations, are discussed below.

\section{Issues of Concern}

\section{A. System Safety}

The Board defines a system safety program as one that provides a life-cycle application of safety engineering and management techniques to the design of system hardware, software, and operations. Such a program should be staffed by professional system safety engineers whose duties are dedicated to safety.

The Board believes that the DOE has neither such a program nor such dedicated technical personnel. For example, there is no organization or person with the dedicated mission of providing system safety management and engineering. General industry, chemical plants, and various federal agencies, such as the Department of Defense, require system safety analysis of major undertakings. The DOE's failure to provide this expertise deprives its civilian waste program of evaluations that might document state-of-the-art safety analysis.

\footnotetext{
${ }^{7}$ This section is based primarily on the work of the Containers and Transportation Panel. It addresses issues of concern and recommendations on transportation. Container issues will be addressed in subsequent reports and will be based in part on information gathered by the Board during a Panel meeting at Lawrence Livermore National Laboratory in January 1990.

${ }^{8}$ Lindsay Audin, A Review of Human Reliability Issues in the Transportation of Spent Nuclear Fuel, pp. 13-25, Prepared for Delos Associates, RR1, Joy Road, Woodstock, CT (May 8, 1988).

${ }^{9}$ S. Tular, R. Kasperson and S. Ratick, The Effects of Human Reliability in the Transportation of Spent Nuclear Fuel, pp. 16-18 (Worchester, MA: Clark University, Center for Technology, Environment, and Development, June 1988).
}

At present, the DOE's contractors for the From-Reactor Cask Program are nearing the Preliminary Design Review Phase. Typically, at this stage a system acquisition program would require a safety engineering program with a documented preliminary hazard analysis report.

The report would provide a systematic analysis that details all operational and functional risks of the preliminary design, with recommendations for their control. Based on information provided to the Board by the DOE, this basic system safety engineering activity and documentation has not been required of the From-Reactor Cask contractors.

The Board considers a system safety program to be essential for both repository design and transportation operational preclosure activities. Such a program should be provided to help assure Congress and the people of the United States that safety has been given appropriate priority.

\section{B. Human Factors}

A human factors program provides a life-cycle application of what is known about human psychological, physiological, and physical limitations in the design and operation of systems to optimize system safety and operability. A human factors program addresses such design issues as human error and is staffed by professional human factors scientists and engineers.

It appears to the Board that the DOE does not have such a program or the personnel to staff such a program. As a result, there are no human factors engineering professionals staffing a human factors engineering program for transportation. Cask design and fabrication human errors have occurred in the past. ${ }^{8,9}$ Experience has shown that in hazardous materials transportation 
a majority of accidents are attributed to human error. ${ }^{10,11}$

Human factors programs, which are commonly employed in major defense system acquisition programs and in industry, are acknowledged to contribute substantially to the reliability and safety of complex systems. A human factors program has been recognized as a needed discipline for nuclear safety in general. The engineering application of this discipline to $\mathrm{DOE}$ activities should not be overlooked. A report of the National Research Council states that it has long been established that human error plays a major role in the malfunctioning of complex, technological systems and in accidents associated with their operation. In the nuclear industry, estimates of the incidence of human error as a percentage of all system failures range from 20 to 65 percent depending on which event data base is used. ${ }^{12}$

A human factors program is applicable to the repository preclosure activities of the DOE, and a lack of such a program compels the Board to recommend that the DOE make a human factors engineering program part of its repository preclosure activities, including transportation activities.

\section{Risk Assessment and Management}

\section{Operational Planning}

Starting in the 1970 s, the DOE and its predecessors developed MORT (Management Oversight Risk Tree), which is presently being maintained by EG\&G in Idaho. This 1,500-node logic

\footnotetext{
${ }^{10}$ M. Abkowitz, S. Abkowitz and M. Lepofsky, Analysis of Human Factors Effects on the Safety of Transporting Radioactive Waste Materials, TR BMI/OTSP-04, p. vii \& 15+, Prepared for Office of Transportation Systems and Planning. Battelle Nuclear Systems Group, 505 King Avenue, Columbus, Ohio (April, 1988).

${ }^{11}$ U.S. Office of Technology Assessment, Transportation of Hazardous Materials, p. 5 \& $81+$ (Washington, D.C.: U.S. Government Printing Office, July 1986).

${ }^{12}$ N.P. Moray, and B.M. Huey, Human Factors Research and Nuclear Safety, p. 71 (Washington, D.C.: National Academy Press, 1988).
}

tree could be applied to the transportation operational planning program to ensure that a broadbased and complete risk assessment and management program is developed. OCRWM personnel could enhance their operational program by evaluating and using this existing DOE tool.

MORT was developed to minimize the risks in operational plans and programs. Its basic logic is that accidents occur from two generic causes: accepted risks and oversight. If a risk is examined carefully and determined to be acceptable or tolerable, no extraordinary steps are undertaken to avoid it. However, procedures should not permit failures due to oversight. Those risks that are not tolerable must be identified, and actions must be taken to correct unnecessary hazards. MORT is an available tool that can assist operational program planners to examine foreseeable risks. It also can assist planners in developing programs that are designed to manage risks effectively. The Board recommends that OCRWM use MORT, or its equivalent, in the transportation operational planning program.

\section{RADTRAN/TRANSNET}

RADTRAN (now version 4.0) is a model and computer code used to assess the risks of transporting radioactive materials under both incidentfree and accident conditions. TRANSNET is a computerized planning tool consisting of a collection of models that select routes, estimate risk, and/or perform system and cost analyses.

The Board believes that RADTRAN is a valuable tool for estimating transportation risks and, thereby, providing input to decision-making. Its use is spreading. The Board is encouraged by the fact that RADTRAN has been adapted for international use by member nations of the International Atomic Energy Agency.

Several avenues should be pursued to further RADTRAN's acceptance and use. The Board believes one of the most important issues that should be addressed is that of model validation. The need exists to demonstrate the validity of 
the underlying assumptions, the plausibility of sub-models, and the reasonableness of results. It is also necessary to quantify the degree of accuracy associated with estimates of transportation risk by calculating associated confidence limits for the estimate.

The Board therefore supports the DOE's intent to conduct an independent peer review of RADTRAN. The Board endorses such an endeayor, provided such a review is conducted under the auspices of a group or organization that is totally independent of the DOE. The Board believes an independent peer review is a sound step in the model validation process. It is, however, only a step. The DOE should establish a plan for the systematic validation of the RADTRAN model in a comprehensive, scientific fashion to ensure that every significant feature is consistent with independent evidence wherever such evidence is available or wherever it can be generated with a reasonable level of effort. Validation should be extended to some of the other models in the TRANSNET package, especially the highway and railroad network representations.

The Board believes the DOE's efforts to provide technical assistance to state, local, and tribal governments should be continued and improved. Packages such as TRANSNET can be improved in terms of both: (1) the capabilities they possess to perform certain analytical functions, and (2) the ease with which the typical user performs analysis and develops insights.

There are a number of potential opportunities for improving the RADTRAN/TRANSNET analytical capabilities. The present practice is to use TRANSNET to select a route by optimizing certain specified and user-weighted criteria. Then, the risk of that route is evaluated with RADTRAN. The procedure does not necessarily identify the route with the least risk, nor is risk combined with other criteria if so desired. The Board recommends that risk be incorporated into route selection tools. The consideration of risk is important as a multi-attribute decision-making problem that includes multiple criteria and objectives. A capability should be provided that permits examination of expected risk (the RADTRAN measure), the risk of extreme events (the measure of greatest concern), and the risk of any accident. It is also important to be able to consider such risks in an optimization or efficiency technique, which permits their combination with other transportation criteria. In addition, the means and consequences of weighting these criteria should be re-examined. How these criteria are weighted is determined largely by the perspective the user brings to the analysis. TRANSNET should incorporate a capability to optimize according to these measures-e.g., expected risk or a combination of risks. In consultation with its user groups, the DOE should identify what additional analytical capabilities should be incorporated into the risk analysis tools.

There are several potential ways of improving RADTRAN useability. RADTRAN is designed to satisfy a variety of applications in the transportation of radioactive materials. Those interested in civilian radioactive waste transportation do not need many of the options RADTRAN provides, such as producing risk data for all radioactive materials. Such information would probably be confusing and distracting to the state and local user, who must be especially prepared to use the tool appropriately. If a RADTRAN/ TRANSNET type of package, designed for users whose principal interest is in civilian nuclear waste transportation, were developed, inappropriate uses and conclusions might be avoided. The $\mathrm{DOE}$ should investigate the gains in user ease that can be made at the cost of wide applicability. A second area where gains in useability can be made lies in trading precision of phenomenon modeling for fewer input parameters and faster turnaround: that is, reducing the complexity of the component models to produce information that is easier to use and to permit smaller computational requirements. 
In summary, the DOE should examine the potential RADTRAN/TRANSNET user community and assess its needs with respect to systems, risk, and cost analyses. Such an assessment could lead to a better determination of how, and to what extent, the DOE portfolio of tools should be modified.

\section{Recommendations}

1. The DOE should initiate a system safety program. The Board will meet with both the DOE and the NRC to encourage this goal.

2. The DOE should initiate a human factors program. The Board plans to meet with both the DOE and the NRC to encourage this goal.

3. The DOE should evaluate the use of riskbased planning tools (such as MORT) in developing a broadbased and complete operational plan that encompasses system safety. The Board will meet with the DOE to explore the use of such tools.

4. The DOE should begin the process of validating the RADTRAN model. This includes: (1) a demonstration of the validity of the underlying assumptions and the component sub-models and the reasonableness of the results, and (2) a quantification of the degree of accuracy of the risk estimates by calculating their associated confidence limits.

5. The DOE should assess the needs of potential risk model users with respect to what civilian radioactive waste program users want to accomplish and the levels of detail they require for different applications. Such a needs assessment would lead to a determination of: (1) the type of analytical capabilities that should be added or improved, and (2) the extent to which generality of applicability and resolution of data can be traded for enhanced useability.

\section{Section 5: Environment and Public Health ${ }^{13}$}

The Board's tasks in the areas of environmental and public health protection included analyzing the overall protection program as well as the regulatory limitations and requirements to which it must adhere. The Board has reviewed both of these areas. In evaluating the regulatory guidelines, the Board looked specifically at $40 \mathrm{CFR}$ 191, the EPA "Environmental Radiation Protection Standards for Management and Disposal of

${ }^{13}$ This section is based primarily on the December 1989 report to the Board of the Environment and Public Health Panel. The report reflects 10 months of work by the panel, including technical meetings and information exchanges with representatives of the DOE, the NRC, the EPA, and the State of Nevada.

${ }^{14}$ Environmental Program Overview, DOE/RW-0207 (Washington, D.C.: U.S. Department of Energy, Office of Civilian Radioactive Waste Management, December 1988).
Spent Nuclear Fuel, High-Level and Transuranic Radioactive Wastes." The Board's findings and recommendations in these areas are included in this section.

\section{The Environmental and Public Health Program}

The DOE environmental and public health program is generally described in the report Environmental Program Overview. ${ }^{14}$ Major components of the program implementation processes are shown in the diagram for OCRWM's environmental process, which is taken from that report (see Figure 7). 


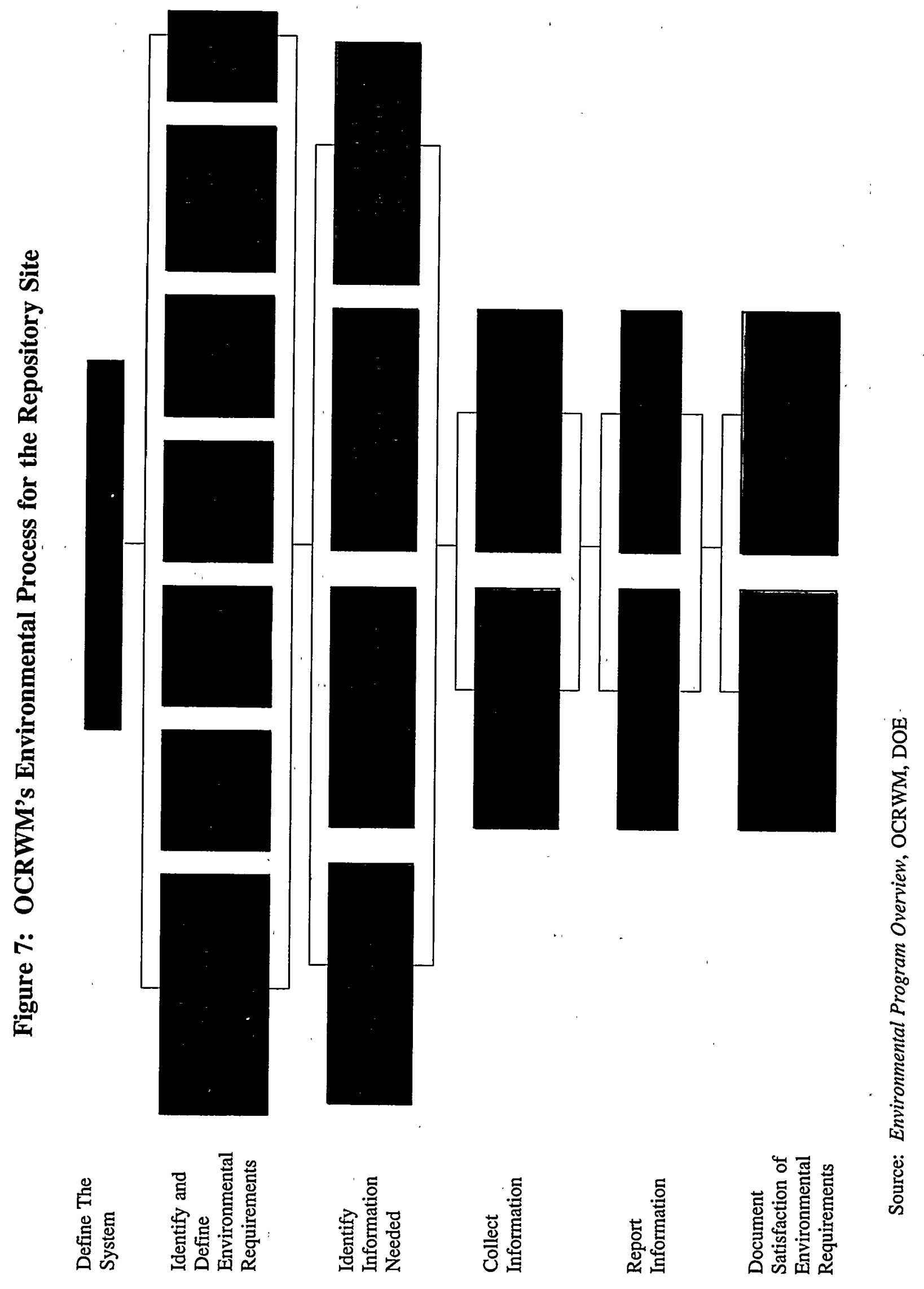


To the left of the diagram is a list of steps that define the program.

- Identify and define environmental requirements.

- Identify information needed.

- Collect information.

- Report information.

- Document satisfaction of environmental requirements.

The Environmental Program Overview, which discusses each component in some detail, also describes the important federal and state regulations that apply to site characterization and repository development at the Yucca Mountain Site. There are direct conflicts between federal requirements and requirements of the State of Nevada in several environmental areas. These issues are discussed in this report and considerably amplified in the report Environmental Regulatory Compliance Plan for Site Characterization. $^{15}$

\section{A. Water Resources}

Concerns about water resources center on three points: contamination, overuse, and changes in groundwater flow patterns. Possible sources of contamination during site characterization and repository construction and operation are: (1) the trace amounts of radionuclides (if used) and other tracers employed in characterization studies; and (2) the introduction of biological and other contamination from sewage. While the small amounts and short half-lives of radionu-

\footnotetext{
${ }^{15}$ Environmental Regulatory Compliance Plan for Site Characterization, Revision 1, DOE/RW-0177 (Washington, D.C.: U.S. Department of Energy, Office of Civilian Radioactive Waste Management, December 1988).
}

clides that might be used in characterization should preclude any impact on the public, the disposal of sewage during any phase of the program could be a problem, and as such has received little attention by the DOE.

Estimates of the projected levels of groundwater use during site characterization are apparently based on the assumption that such use will be minor compared to present water use by the Nevada Test Site (NTS) and greater Las Vegas areas. However, steps can be taken to reduce water consumption during site characterization and, if the site proves acceptable, consumption can be reduced even more during construction and operation of the repository. Efforts to examine such options appear to have been minimal.

Since the public perceives water resources to be important in an arid environment such as southern Nevada, it appears to the Board that a more sensitive and rigorous approach to research on water conservation options during site characterization and later operational stages might contribute to improving relationships between the DOE and the public.

The DOE released a report on groundwater level measurements in early 1990, and the U.S. Geological Survey will release one in March. The Board will examine these, both in terms of the techniques used and the emerging patterns of groundwater levels and flow patterns.

Installing a tighter network of saturated and unsaturated zone test wells and proceeding with radionuclide/tracer experiments on groundwater movements are necessary to interpret the tentative groundwater flow patterns and rates, which are important for characterizing potential radionuclide migration away from the future repository. The Board realizes that these activities and their schedules must be based on technological feasibility and resource availability. Nevertheless, the response of the water table to recharge is important to the protection of the environment and public health, and the adequacy of the additional efforts will be easier to judge after 
publication of the two reports referred to in the previous paragraph.

\section{B. Air Resources}

The existing and projected studies of atmospheric conditions in the Yucca Mountain area are of high quality. Certainly the baseline information will be adequate for detecting the environmental impacts of site characterization and subsequent repository construction and operation if the site proves acceptable. This network will also provide a better detailed characterization of the topographic impacts on point-to-point variations in local climates.

During the operating and closure periods, releases of hazardous materials into the atmosphere at the site will most likely come from gaseous products. Releases during site characterization and construction are very modest when compared with past and ongoing operations at the NTS and various smelting, power plant, and chemical plant operations in the Southwest. Research plans to monitor this risk potential for the Yucca Mountain area seem to be satisfactory.

\section{Soils Studies}

The soils characterization plan for the Yucca Mountain Site and environs seems poorly articulated when compared to other environmental field activity plans. The plan lacks a functional ecosystem linkage to risk assessment and mitigation.

For example, the definition of mitigation in the "Environmental Field Activity Plan for Soils" is taken from the Council on Environmental Quality regulations and includes a statement that an impact may be rectified by repair, rehabilitation, or restoration. ${ }^{16}$ This statement specifically covers reclamation. However, in mitigating disturbed soil areas, the use of revegetation is briefly discussed in the referenced reclamation

${ }^{16}$ Title 40, Code of Federal Regulations, Chapter 5, 1508.20 (c), p. 1049 (July 1, 1988). document but not emphasized in any of the planned soil or reclamation studies.

Soils studies clearly should be part of an ecosystem characterization effort that links geology, meteorology, water, and biology into coherent systems that then can be assessed for vulnerabilities and mitigative efforts.

\section{Biological Resources}

There are potentially significant biological risks related to both the site characterization plan and any future construction and operation of a high-level nuclear waste repository. However, there is nothing about the proposed activities that makes them different in kind or intensity from currently permitted activities such as mining, construction, and pumped irrigation in southern Nevada. Several biological species that occur on the Yucca Mountain Site itself, the most prominent being the desert tortoise, warrant special mitigative attention.

The approach of the ongoing and planned research on biological aspects of the Yucca Mountain Site is piecemeal and species-population specific, thus lacking an overall systems approach. The focus is on ensuring compliance with specific regulations. More effective, however, would be efforts to characterize and understand the operation of the desert ecosystems. The need exists to determine the extent to which site characterization activities and repository construction and operation would impact desert ecosystems. Biological impacts should be enumerated, potentially vulnerable ecosystems should be characterized, and greenhouse and field experiments should be performed. The objective of this effort should be not only to assess the potential impact of repository construction on desert ecosystems, but also to determine ways to mitigate the impact. Such a coherent plan does not emerge from the array of ongoing and planned individual field research projects, which are not very clearly articulated. While individual existing plans address specific 
regulatory issues, potential risks to the whole desert ecosystem must be addressed and mitigating actions planned.

The Ash Meadows endemic species center, lying 27 miles south-southeast of Yucca Mountain, constitutes the potentially most biologically sensitive area in the Yucca Mountain region. The site characterization activities themselves are unlikely to create any significant risk to these endemic and rare ecosystems with their special species populations. The risk may come from construction and operation of the repository and its potential long-term impacts on the amount, temperature, and chemistry of the groundwater reaching the surface in the 25 Ash Meadows springs. Obviously, accurate characterization of present and potential changes in groundwater flows and chemistries is essential, as are more intensive schemes for water conservation during site characterization and any subsequent repository construction and operating phases. A more focused ecosystem approach would be necessary to assess these risks.

\section{E. Cultural Resources}

The DOE Cultural Resources Program is divided into two major components: archaeological and Native American cultural issues. Studies in these areas are being done by the Desert Research Institute of the University of Nevada, Reno. These studies seem comprehensive in scope and likely to elicit interest of Native American groups in the area. The quality of the planned research is impressive.

This is also an area of cooperative efforts among scientists working on the OCRWM programs and those employed by the State of Nevada (e.g., scientists with the Nevada Division of Historic Preservation and Archaeology).

\section{F. Radiological Studies}

The radiological monitoring program is an extension of long-term, comprehensive moni- toring activities that are conducted in and around the NTS. They are carried out routinely at NTS to monitor possible radiological contamination, which is an order of magnitude higher than contamination from contemplated activities at a high-level nuclear waste repository.

Extending the current monitoring program to cover the Yucca Mountain Site will make good use of the wide range of baseline data and expertise that exist in organizations currently engaged in site work.

Quality assurance is very important in the radiological studies, as it is in each individual component of the site characterization program. Care must be taken to ensure that these aspects of the program are described accurately and reflect state-of-the-art science and technology.

\section{Radiation Protection Standards}

The radiation protection standards that must be met by a high-level nuclear waste repository will be contained in 40 CFR 191, "Environmental Radiation Protection Standards for Management and Disposal of Spent Nuclear Fuel, HighLevel and Transuranic Radioactive Wastes." At this time, Subpart B of 40 CFR 191 has been remanded back to EPA for several specific reasons. It is primarily this Subpart that is undergoing review and change by the EPA, although some modification may occur in other parts.

It is worth noting that the Nation is simultaneously embarking on two new ventures. The first consists of the DOE's efforts to characterize the site and determine its suitability. Simultaneously, regulations are evolving that will have an impact on site characterization activities and on the design, construction, and operation of a waste repository.

In its review of the first working draft of the revision to $40 \mathrm{CFR} 191$, the Board noted seven items worthy of comment. 
First, in Section 191.13, "Containment Requirements," the release limits discussed in this Section (and contained in Table 1 of Appendix B, Section 191.13) appear very conservative and inconsistent with present day regulatory practice and scientific consensus. An example of this relates to ${ }^{14} \mathrm{C}$, which is routinely released by nuclear power plants and fuel reprocessing plants, was released in atmospheric weapons tests, and is generated continuously and naturally by cosmogenic means in the atmosphere. The annual doses predicted from ${ }^{14} \mathrm{C}$ release from the high-level nuclear waste repository are very small fractions of those currently being received from the ${ }^{14} \mathrm{C}$ produced from previous nuclear weapons tests and even smaller when compared to doses from naturally produced ${ }^{14} \mathrm{C}$. Comparison with current allowable exposures of the public to ${ }^{14} \mathrm{C}$ indicates the large degree of conservatism contained in Table 1, Appendix B of 40 CFR 191.

Second, Item c. of Section 191.13, "Containment Requirements," is vague and given almost as an afterthought. It specifically deals with projected release rates between 10,000 and 100,000 years after disposal, which "should not be much greater than those allowed in Item a." Where Item a. covers release rates in numerical terms for the 10,000 years after disposal, it is pertinent to note that within 10,000 years, high-level nuclear waste will have approached natural ores in terms of its radiological hazard.

Third, in Section 191.14, "Assurance Requirements," the requirement for monitoring is openended and could imply monitoring forever. It states, "monitoring ... shall be conducted until there are no significant concerns to be addressed by further monitoring." It would seem more appropriate to identify such significant concerns and propose monitoring until the concerns have been appropriately addressed. This requirement may conflict with the general position that longterm (greater than 100 years) maintenance and administration of the site should not be expected or required.
Fourth, Section 191.14, "Assurance Requirements," Item d. states, "Disposal systems shall be selected and designed to keep releases to the accessible environment as small as reasonably achievable, taking into account technical, social, and economic considerations." Meeting the requirements of $40 \mathrm{CFR} 191$ should ably and amply qualify as having responded in the affirmative to the concept of As Low As Reasonably Achievable (ALARA). The question can also be legitimately raised as to the appropriateness of the ALARA philosophy as it is applied to a high-level nuclear waste repository.

A fifth item is contained in Appendix C, "Guidance for Implementation of Subpart B," which is not an integral part of 40 CFR 191. It contains guidance for the implementing agencies. The concern is expressed in the words, "Because the procedures for determining compliance with Subpart B have not been formulated and tested yet ... ." It would be helpful if the EPA would give explicit information on one or more realistic scenarios of how key data could be used in the determination of compliance with the critical requirements of Subpart B.

Sixth, in Appendix C, "Guidance for Implementation of Subpart B," the discussion relates to inadvertent human intrusion. The number of boreholes per square kilometer of repository area per 10,000 years seems related to Item 2 above, although it is unclear how the groundwater could flow to the surface.

A seventh item is the uncertainty and limitations in determining the values of geological parameters. It is not apparent how these uncertainties are to be characterized and what burden of evidence is needed to meet the requirements of 40 CFR 191.

\section{Issues of Concern}

In discussing environmental aspects of site characterization at Yucca Mountain, it is obvious that a majority of the planned program cannot 
proceed without the cooperation of the State of Nevada. Many applications have been filed with the State by the DOE, and these have been met by delays of up to 2 years. Thus, much of the site characterization is on hold until this serious impasse between the DOE and the State of Nevada is resolved.

The second issue of concern is the need for an integrated ecosystem program of studies as an integral part of site characterization at Yucca Mountain. There are many very good studies underway on the ecosystem, but they lack a central focus, which would integrate work in soils, weather, water, and biology.

The third issue is the suitability and practicality of 40 CFR 191. As noted above, the Board has several concerns related to this regulation.

\section{Recommendations}

In the two areas under consideration, the environmental program and regulatory matters, the Board has the following recommendations.

\section{A. Environmental and Public Health Protection Program}

Since implementation of the site characterization plan, of which the environmental program is a part, depends on ready access to the site and the initiation of detailed experimental studies, it is necessary to resolve the current impasse on permitting with the State of Nevada. The Board urges both parties to constructively resolve the matter and notes the recently announced DOE intentions in this area.

The DOE should develop a systems approach to its Yucca Mountain ecosystems studies. Each individual study should be an integral part of an overall ecosystem program. Present studies lack interdisciplinary coordination, as noted elsewhere. The Board recommends that the DOE examine its ecosystem program in general with a view toward improving the degree of coordination among its various facets.

\section{B. Regulatory Matters}

\section{Standard 40 CFR 191}

The Board is concerned with several aspects of the requirements that may be included in 40 CFR 191 and therefore must be met by the DOE. The following recommendations reflect those concerns. The Board recommends that the following modifications should be considered when the Standard: 40 CFR 191 is revised.

- The large degree of conservatism, which is expressed in Section 191.13 and contained in the numerical values in Table 1, Appendix B of that Section, should be re-evaluated in view of present-day environmental and regulatory requirements and, also, when appropriate, in view of exposures received routinely and continuously from naturally occurring radiation.

- The vagueness contained in Item c. of Section 191.13 regarding numerical releases of radioactivity in the period 10,000 to 100,000 years postclosure should be removed from 40 CFR 191.

- The monitoring requirements specified in Section 191.14 should be expressed in more definitive terms.

- The requirement for use of the concept of ALARA in Section 191.14 should be removed for two reasons. First, there is a question of appropriateness and applicability to the high-level radioactive waste repository. Second, if the requirements of 40 CFR 191 can be met, it seems this accomplishment would certainly qualify as ALARA. 
- Additional guidance should be given in Appendix $\mathrm{C}$ as to the procedures that must be followed by the implementation agencies to determine compliance with the requirements of Subpart B.

- Additional guidance should be given in Appendix $\mathrm{C}$ as to the process of groundwater flow to the surface.

\section{Licensing Standards and Criteria}

More attention should be given to inherent uncertainties and limitations in geologic information and data projected for periods of tens of thousands of years in regard to the rigor of formulating acceptable and realistic environmental radiation protection standards.

\section{Section 6: Summary of Recommendations}

In the previous five sections, the Board presented its findings and concerns over a wide range of topics and presented a total of 24 recommendations. In this section, these recommendations have been regrouped into three categories: Technical and Scientific; Strategic Technical and Non-Technical; and Science Policy (see Figure 8). This summation, while not a ranking or rating process, provides the reader with an easy reference to the Board's present concerns, questions, and specific recommendations for the direction of the program. Topics are listed according to their appearance in Sections 1 through 5.

\section{Technical and Scientific Recommendations}

These recommendations address questions such as: What is the significance of the volcanism at the Yucca Mountain Site?, Does the Ghost Dance Fault, or other geologic faults, seriously affect the suitability of the Yucca Mountain Site? What techniques should be used for sinking shafts and driving tunnels in a repository? The Board's objective will be to identify the most important technical and scientific issues that the DOE should analyze further and to specify a possible course of action. Seventeen recommendations are presented in this category.

\section{A. Mechanical Excavation}

The Board recommends that the DOE maximize the use of the most modern mechanical excavation techniques in the recently initiated studies of alternative shaft and tunnel construction methods in order to reduce disturbance to the rock walls and to achieve greater economy of time and cost.

\section{B. Ghost Dance Fault}

The Board recommends that the Ghost Dance Fault be intersected with an exploratory drift at more than one location so as to obtain a better three-dimensional picture of the fault's physical properties.

\section{Early Exploratory Drifting}

The Board recommends that the DOE definitively plan an additional early exploratory drift in an east-west direction across the Yucca Mountain geologic block so as to reduce uncertainties and to increase confidence as early as possible that potentially disqualifying geologic features do or do not occur. 
Figure 8: Board Recommendations $\mathrm{s}^{\mathrm{a}}$
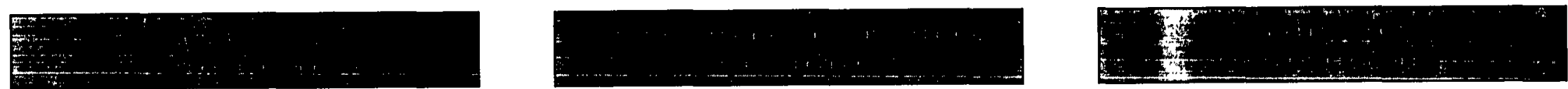
A. Mechanical Excavation
A. System Safety
A. DOE/State of Nevada Interactions
B. Ghost Dance Fault
B. Human Factors
B. The EPA Standard: 40 CFR 191
C. Early Exploratory Drifting
C. Operational Planning
D. Exploratory Ramp
E. Non-Welded Tuff
D. Environmental and Public Health
C. Uncertainties in Setting Standards

F. Excavation-Testing Sequence

G. Unsaturated Zone Recharge

H. Fracture Flow

I. Hydrogeologic Modeling

J. Calico Hills Hydrogeological Properties

K. Adsorption in Unsaturated Tuffs

L. Radionuclide Adsorption Workshop

M. Performance Assessment Methodology

N. Preliminary Performance Assessment

O. RADTRAN/TRANSNET

P. Risk Models User-Needs Assessment

Q. ${ }^{14} \mathrm{C}$ Release Mechanism

${ }^{\text {a }}$ This is not a ranking. Topics are listed according to their appearance in Sections 1 through 5 . 


\section{Exploratory Ramp}

The Board recommends that the DOE continue the studies for incorporating an exploratory ramp entering the Yucca Mountain geologic block from the east. Such a ramp would allow the known fault zone and the different tuff units that occur between the surface facilities and the repository area in Yucca Mountain to be crossed and inspected at depth.

\section{E. Non-Welded Tuff}

The Board recommends that the DOE include in the exploratory program ample penetration of the softer, less permeable tuff units by borings, shafts, ramps, or tunnels so that inspection, mapping, and testing of these critical units can be conducted, both above and below the repository level.

\section{F. Excavation-Testing Sequence}

The Board recommends that the DOE develop innovative ways of coordinating and sequencing the excavation and scientific testing so that both programs can be executed in a timely manner without sacrificing the scientific validity of the testing.

\section{G. Unsaturated Zone Recharge}

The Board recommends that the DOE expand and accelerate the studies of snowmelt and rainfall infiltration into alluvium and near-surface fractures.

\section{H. Fracture Flow}

The Board recommends that the DOE continue the sampling and analysis of ${ }^{3} \mathrm{H}$ and ${ }^{36} \mathrm{Cl}$ isotopes in order to gain a better understanding of the surface features that control this deep penetration of recharge.

\section{Hydrogeologic Modeling}

The Board recommends that the DOE approach hydrogeologic modeling in the program in a more systematic fashion. All predictive hydrogeologic models should be validated each time new pertinent field data are made available. Validation should be a continuous iterative process. The relationship between the use of deterministic and stochastic models should be clarified.

\section{J. Calico Hills Hydrogeologic Properties}

The Board recommends that the DOE explore the Calico Hills unit with surface borings and with the exploratory shaft facility. See also Recommendation E.

\section{K. Adsorption in Unsaturated Tuffs}

The Board recommends that the DOE study radionuclide adsorption in unsaturated tuffs over the range of temperatures and variable conditions of $\mathrm{pH}$, ionic strength, and competing and complexing aqueous ionic species concentrations expected at the site.

\section{Radionuclide Adsorption Workshop}

The Board recommends that the DOE organize a radionuclide adsorption workshop to be attended by the DOE and its contractors involved in the measurement and modeling of such adsorption. The workshop would have two general purposes.

- To determine the applicability of available radionuclide adsorption data on tuff and models for predicting such adsorption under existing and postclosure conditions at Yucca Mountain.

- To establish what additional radionuclide adsorption research and model develop- 
ment are needed. Such research and model development should: (1) attempt to demonstrate that quantitative, scientifically defensible predictions of radionuclide adsorption at Yucca Mountain are possible; and (2) show how such measured and predicted adsorption relates to compliance with the radionuclide release rate criteria set forth in 40 CFR 191.

\section{Performance Assessment Methodology}

The Board recommends that the DOE develop the methodology needed to demonstrate that performance assessments can be carried out.

\section{N. Preliminary Performance Assessment}

The Board recommends that the DOE promptly carry out preliminary performance assessment calculations to demonstrate that: (1) such computations are possible, and (2) no site characteristic has yet been detected that would disqualify the site.

\section{O. RADTRAN/TRANSNET}

The Board recommends that the DOE begin the process of validating the RADTRAN model and some components of the TRANSNET package. This includes: (1) a demonstration of the validity of the underlying assumptions and the component sub-models and the reasonableness of the results, and (2) a quantification of the degree of accuracy of the risk estimates by calculating their associated confidence limits.

\section{P. Risk Models User-Needs Assessment}

The Board recommends that the DOE assess the needs of potential civilian radioactive waste program RADTRAN/TRANSNET users with respect to what users want to accomplish and the levels of detail they require for different applications. Such a needs assessment would lead to a determination of: (1) the type of analytical capabilities that should be added or improved, and; (2) the extent to which the model can be tailored to specific user needs.

\section{Q. ${ }^{14} \mathrm{C}$ Release Mechanism}

The Board recommends that the DOE expand its studies of ${ }^{14} \mathrm{C}$ release mechanisms and initiate a consultive program with the EPA and the NRC to examine the appropriateness of the ${ }^{14} \mathrm{C}$ limit itself.

\section{Strategic Technical and Non-Technical Recommendations}

Strategic technical recommendations involve value judgments about technical and non-technical factors. Such issues include: When do we have enough technical information and analysis to make decisions about repository development? Is the current decision-making and operational structure adequate to successfully carry the Nation through repository construction and operation over the next several decades? On such matters, the Board will attempt to explain the issues more clearly, suggest possible mechanisms or processes for addressing and/or resolving the issues, or make judgments on them. The Board has developed four recommendations on issues of this type that it feels need to be addressed by the DOE.

\section{A. System Safety}

The Board recommends that the DOE initiate a transportation system safety program. The Board will meet with both the DOE and the NRC to encourage this goal.

\section{B. Human Factors}

The Board recommends that the DOE initiate a human factors program for transportation 
safety. The Board plans to meet with both the $\mathrm{DOE}$ and the NRC to encourage this goal.

\section{Operational Planning}

The Board recommends that the DOE evaluate the use of risk-based planning tools (such as MORT) in developing a broadbased and complete transportation operational plan that encompasses system safety.

\section{Environmental and Public Health Program}

The Board recommends that the DOE develop a systems approach to its Yucca Mountain ecosystem studies program and that each individual study should be integrated into an overall environmental program.

\section{Science Policy Recommendations}

Science policy recommendations involve decisions typically dealt with in the upper echelons of the Executive Branch or Congress. Such issues involve storage, disposal, and transportation of spent fuel; the development of EPA standards and NRC regulations; and the repository licensing process. For example, the strategic question, "Is Yucca Mountain suitable as a site for the permanent repository?" is related to other public policy issues. Three recommendations are presented in this category.

\section{A. DOE and State of Nevada Interactions}

The Board recommends that the DOE continue its efforts to resolve the present impasse on permitting of site characterization studies. Unless the impasse is resolved, the Yucca Mountain Site cannot be characterized because needed scientific and technical work cannot proceed.

\section{B. The EPA Standard: 40 CFR 191}

The Board recommends that certain modifications should be considered when the EPA Standard: 40 CFR 191 is revised.

\section{Consideration of Uncertainties in Setting Standards}

The Board recommends that the DOE request the regulatory agencies to consider inherent uncertainties and limitations in geologic information and data projected for periods of tens of thousands of years in regard to the rigor of formulating acceptable and realistic environmental radiation protection standards. 


\section{Chapter 3 \\ Cross-Cutting Issues for Future Inquiry}

Chapter 2 provides recommendations based on the Board's work to date. Several issues, however, cut across the substantive areas covered so far by the individual panels. These issues are discussed briefly according to the following topics: a systems engineering and analysis approach to waste management; the relative importance of natural and engineered barriers; the thermal loading of a repository; repository suitability and licensing standards; and current Department of Energy (DOE) priorities. The five topics will be explored in the future.

In addressing the fifth topic, "current DOE priorities," the Board wishes to acknowledge the U.S. Secretary of Energy's report to Congress. ${ }^{1}$ The main points of the Secretary's report also will be addressed further in the Board's upcoming deliberations.

\section{Issue 1: A Systems Engineering and Analysis Approach}

Systems engineering and analysis (SEA) is a set of procedures that provides a means of coordinating, integrating, and controlling large, complex scientific and engineering programs. ${ }^{2}$ SEA could help establish procedures for building a

${ }^{1}$ Report to Congress on Reassessment of the Civilian Radioactive Waste Management Program (Washington, D.C.: U.S. Department of Energy, Office of Civilian Radioactive Waste Management, November 29, 1989).

${ }^{2}$ SEA originated in the 1960 s when the process was created and used successfully in the U.S. Navy's Polaris Fleet Ballistic Missile Submarine Program and the Apollo Manned Lunar Landing Program. repository for the permanent disposal of spent nuclear fuel and high-level waste. It is a process that can analyze the technical and non-technical implications of decisions, make provisions for contingencies, and select nearly optimal solutions to problems that may arise. To be effective, however, SEA requires extensive coordination and advance planning.

An SEA approach is used to analyze and better understand the relationships and interactions among elements of a complex system. An SEA approach to waste management would facilitate

- innovative planning of excavation activities and associated scientific testing, as described in Section 1 of Chapter 2;

- developing and validating hydrogeologic models, as described in Section 2;

- conducting performance allocation and performance assessment, as described in Section 3;

- optimizing transportation system safety and operational planning, as described in Section 4; and

- integrating the DOE's environmental program with the overall licensing effort, as described in Section 5.

Many key features of an effective SEA program could enhance the DOE's site characteriza- 
tion program. Such key features include addressing all important elements, establishing technical priorities, integrating individual efforts, and establishing credible time schedules. However, understanding all aspects of spent fuel management and disposal is certainly not an easy task. Furthermore, the involvement of many national laboratories and contractors may make program coordination and integration difficult to perform. Therefore, the Board intends to request a briefing from the DOE to examine the DOE's current and future plans in this important area.

\section{Issue 2: The Relative Importance of Natural and Engineered Barriers}

The geologic repository will consist of engineered and geologic barriers that together will isolate spent nuclear fuel and high-level waste from the biosphere for at least 10,000 years. Where natural geologic barriers are deficient, it may be possible to increase the levels of waste isolation by adding long-life engineered barriers. An SEA approach can assist with the design of conservative engineered barriers that are compatible with the geologic barrier.

Current regulations require the isolation of spent nuclear fuel and high-level waste using engineered barriers. The barriers are required to isolate the waste for "not less than 300 years, nor more than 1,000 years after permanent closure of the geologic repository." 3 Thereafter, the overall geologic setting is required to provide waste isolation for up to 10,000 years. These requirements establish the geologic setting as the primary barrier. This necessitates the extensive site

\footnotetext{
${ }^{3}$ Title 10, Code of Federal Regulations, Chapter 1,60.113 (a) (ii) (A), pp. 82-3 (January 1, 1988). The NRC has recently acknowledged the need to clarify the intent of this regulation.

${ }^{4}$ Final Storage of Spent Nuclear Fuel-KBSIII, Vol. III, Barriers, Table 103, p. 10:15 (Stockholm, Sweden: Swedish Nuclear Fuel Supply Co.I Division KBS, May 1983).
}

characterization efforts necessary to obtain an acceptable level of confidence in the long-term performance of the geologic barrier. An extended-life, engineered barrier could significantly increase confidence in the long-term performance of a repository by reducing reliance on geologic barriers. Furthermore, using well-engineered containers could reduce the DOE's heavy reliance on mathematical models of the geologic setting for licensing decisions. Research conducted in Sweden since 1977 suggests that containers can provide at least 10,000 years of isolation for 40-year-old spent nuclear fuel. ${ }^{4}$

Since the Board sees potential advantages associated with developing extended-life, engineered barriers, this approach will be further explored with the DOE and the Nuclear Regulatory Commission (NRC).

\section{Issue 3: Thermal Loading of a Repository}

Even under the best of circumstances, technical uncertainties will persist regarding the performance of any geologic repository. However, the lower the level of uncertainty, the greater the confidence the technical community and the public will have in geologic disposal. When 20year-old spent nuclear fuel is disposed of in a geologic repository, heat is given off by the spent fuel increasing the temperature of the surrounding rock formations (thermal pulse). Uncertainty about a repository's long-term performance is related in part to this thermal pulse.

Many European countries plan to reduce uncertainties associated with geologic disposal by reducing the thermal loading of the repository. This can be done by: (1) allowing the radioactive material in spent nuclear fuel to decay or "cool" prior to disposal, (2) putting less spent nuclear fuel in each canister (at a planned spacing), or (3) increasing the spacing among waste canisters. For example, the heat output from spent nuclear fuel can be reduced by 30 percent by allowing 
20-year-old spent nuclear fuel to age for another 20 years prior to disposal. ${ }^{5}$

This issue will require indepth briefings by the DOE and considerable evaluation by the Board. In such a cost-benefit analysis, for example, the benefits gained by reducing the thermal loading have to be balanced against the possible need for additional waste storage facilities, an increase in the number of waste packages, and the need for more repository capacity.

\section{Issue 4: Repository Suitability and Licensing Standards}

Since no country in the world has yet developed a geologic repository, there is little practical experience upon which to base licensing standards. Furthermore, 10,000 years is an extremely long time period for isolating any type of waste. However, regulatory guidelines have to be developed prior to disposal to ensure public safety and environmental protection.

Licensing standards and criteria for the repository, as promulgated by the Environmental Protection Agency (EPA) and the NRC, must be adequately conservative on the side of safety and protection of the accessible environment. However, the standards should not impose restrictions that would foreclose at the outset a candidate site subsequently shown to be suitable on sound scientific considerations. In this light, the Board has been working with personnel from the EPA, the NRC, and the DOE. The Board expects to continue these activities in 1990.

${ }^{5}$ Ibid, p. 10:15.

${ }^{6}$ Report to Congress on Reassessment of the Civilian Radioactive Waste Management Program (Washington, D.C.: U.S. Department of Energy, Office of Civilian Radioactive Waste Management, November 29, 1989).

\section{Issue 5: Current DOE Priorities}

The U.S. Secretary of Energy concluded in his recent report to Congress that to develop a technically sound integrated waste management system, the DOE needs to implement management improvements, to pursue an orderly program of scientific investigations that is not driven by unrealistic scheduling demands, and to establish a monitored retrievable storage (MRS) facility that is unlinked to the repository construction schedule to allow early acceptance of spent nuclear fuel. ${ }^{6}$

The Board believes that all three topics fit very well into the concept of systems engineering and analysis that allows the integration and control of the diverse technologies and the establishment of priorities. The Board agrees with the DOE's plans to establish priorities and would urge that high priorities be given to the studies of the natural hazards of volcanism, faulting, and earthquakes as well as to the hydrogeologic framework of Yucca Mountain including storm-generated recharge and preferred flow paths along fault zones and welded-tuff interbeds. While much can be learned from surface-based testing, the Board believes strongly that site suitability can be judged adequately only after the exploratory shaft facilities have allowed actual underground inspections and associated testing to be carried out.

The Secretary's third conclusion regarding the need for an MRS facility unlinked to the repository schedule of construction has the potential benefit of making it possible for the federal government to accept spent nuclear fuel from the utilities at an early date. There may be additional potential benefits in temporary storage, including overall system flexibility and the later emplacement of the containers in the permanent repository at a lower temperature. The Board will explore the technical merits concerning the MRS with the DOE over the next several months. 


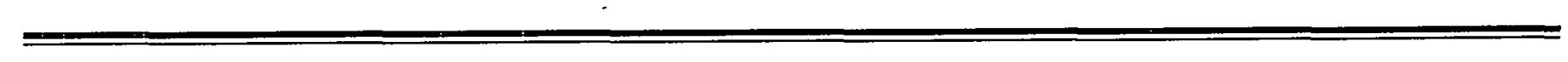




\section{Appendix A \\ Public Law 100-203-December 22, 1987, Part E}

\section{PART E-NUCLEAR WASTE TECHNICAL REVIEW BOARD}

SEC. 5051. NUCLEAR WASTE TECHNICAL REVIEW BOARD.

The Nuclear Waste Policy Act of 1982 (40 U.S.C. 10101 et seq.) is further amended by adding at the end the following new title:

\section{"TITLE V-NUCLEAR WASTE TECHNICAL REVIEW BOARD}

"DEFINITIONS

42 USC 10261. "SEC. 501. As used in this title:

"(1) The term 'Chairman' means the Chairman of the Nuclear Waste Technical Review Board.

"(2) The term 'Board' means the Nuclear Waste Technical Review Board established under section 502.

\section{"NUCLEAR WASTE TECHNICAL REVIEW BOARD}

42 USC 10262.

"SEC. 502. (a) ESTABLISHMENT.-There is established a Nuclear Waste Technical Review Board that shall be an independent establishment within the executive branch.

President of U.S. $\quad$ "(b) MEMBERS.-(1) The Board shall consist of 11 members who shall be appointed by the President not later than 90 days after the date of the enactment of the Nuclear Waste Policy Amendments Act of 1987 from among persons nominated by the National Academy of Sciences in accordance with paragraph (3).

President of U.S. $\quad$ "(2) The President shall designate a member of the Board to serve as chairman.

"(3)(A) The National Academy of Sciences shall, not later than 90 days after the date of the enactment of the Nuclear Waste Policy Amendments Act of 1987, nominate not less than 22 persons for appointment to the Board from among persons who meet the qualifications described in subparagraph (C). 
"(B) The National Academy of Sciences shall nominate not less than 2 persons to fill any vacancy on the Board from among persons who meet the qualifications described in subparagraph (C).

"(C)(i) Each person nominated for appointment to the Board shall be-

"(I) eminent in a field of science or engineering, including environmental sciences; and

"(II) selected solely on the basis of established records of distinguished service.

"(ii) The membership of the Board shall be representative of the broad range of scientific and engineering disciplines related to activities under this title.

"(iii) No person shall be nominated for appointment to the Board who is an employee of-

"(I) the Department of Energy;

"(II) a national laboratory under contract with the Department of Energy; or

"(III) an entity performing high-level radioactive waste or spent nuclear fuel activities under contract with the Department of Energy.

"(4) Any vacancy on the Board shall be filled by the nomination and appointment process described in paragraphs (1) and (3).

"(5) Members of the Board shall be appointed for terms of 4 years, each such term to commence 120 days after the date of enactment of the Nuclear Waste Policy Amendments Act of 1987, except that of the 11 members first appointed to the Board, 5 shall serve for 2 years and 6 shall serve for 4 years, to be designated by the President at the time of appointment.

\section{"FUNCTIONS}

42 USC 10263.

"SEC. 503. The Board shall evaluate the technical and scientific validity of activities undertaken by the Secretary after the date of the enactment of the Nuclear Waste Policy Amendments Act of 1987, including-

"(1) site characterization activities; and

"(2) activities relating to the packaging or transportation of high-level radioactive waste or spent nuclear fuel.

\section{"INVESTIGATORY POWERS}

42 USC 10264.

"SEC. 504. (a) HEARINGS.-Upon request of the Chairman or a majority of the members of the Board, the Board may hold such hearings, sit and act at such times and places, take such testimony, and receive such evidence, as the Board considers appropriate. Any member of the Board may administer oaths or affirmations to witnesses appearing before the Board.

(b) PRODUCTION OF DOCUMENTS.- (1) Upon request of the Chairman or a majority of the members of the Board, and subject to existing law, the Secretary (or any contractor of the Secretary) shall provide the Board with 
such records, files papers, data, or information as may be necessary to respond to any inquiry of the Board under this title.

"(2) Subject to existing. law, information obtainable under paragraph (1) shall not be limited to final work products of the Secretary, but shall include drafts of such products and documentation of work in progress.

\section{"COMPENSATION OF MEMBERS}

42 USC 10265.

"SEC. 505. (a) IN GENERAL.-Each member of the Board shall be paid at the rate of pay payable for level III of the Executive Schedule for each day (including travel time) such member is engaged in the work of the Board.

"(b) TRAVEL EXPENSES.-Each member of the Board may receive travel expenses, including per diem in lieu of subsistence, in the same manner as is permitted under section 5702 and 5703 of title 5, United States Code.

\section{"STAFF}

42 USC 10266.

"SEC. 506. (a) Clerical STAFF.-(1) Subject to paragraph (2), the Chairman may appoint and fix the compensation of such clerical staff as may be necessary to discharge the responsibilities of the Board.

"(2) Clerical staff shall be appointed subject to the provisions of title 5, United States Code, governing appointments in the competitive service, and shall be paid in accordance with the provisions of chapter 51 and subchapter III of chapter 53 of such title relating to classification and General Schedule pay rates.

"(b) PROFESSIONAL STAFF.-(1) Subject to paragraphs (2) and (3), the Chairman may appoint and fix the compensation of such professional staff as may be necessary to discharge the responsibilities of the Board.

"(2) Not more than 10 professional staff members may be appointed under this subsection.

"(3) Professional staff members may be appointed without regard to the provisions of title 5, United States Code, governing appointments in the competitive service, and may be paid without regard to the provisions of chapter 51 and subchapter III of chapter 53 of such title relating to classification and General Schedule pay rates, except that no individual so appointed may receive pay in excess of the annual rate of basic pay payable for GS-18 of the General Schedule.

\section{"SUPPORT SERVICES}

42 USC 10267.

"SEC. 507. (a) GENERAL SERVICES.-To the extent permitted by law and requested by the Chairman, the Administrator of General Services shall provide the Board with necessary administrative services, facilities, and support on a reimbursable basis. 


\section{"(b) ACCOUNTING, RESEARCH, AND TECHNOLOGY ASSESSMENT}

SERVICES.-The Comptroller General, the Librarian of Congress, and the Director of the Office of Technology Assessment shall, to the extent permitted by law and subject to the availability of funds, provide the Board with such facilities, support, funds and services, including staff, as may be necessary for the effective performance of the functions of the Board.

"(c) ADDITIONAL SUPPORT.-Upon the request of the Chairman, the Board may secure directly from the head of any department or agency of the United States information necessary to enable it to carry out this title.

"(d) Malls. - The Board may use the United States mails in the same manner and under the same conditions as other departments and agencies of the United States.

"(e) EXPERTS AND CONSULTANTS.-Subject to such rules as may be prescribed by the Board, the Chairman may procure temporary and intermittent services under section 3109(b) of title 5 of the United States Code, but at rates for individuals not to exceed the daily equivalent of the maximum annual rate of basic pay payable for GS-18 of the General Schedule.

\section{"REPORT}

42 USC 10268.

"SEC. 508. The Board shall report not less than 2 times per year to Congress and the Secretary its findings, conclusions, and recommendations. The first such report shall be submitted not later than 12 months after the date of the enactment of the Nuclear Waste Policy Amendments Act of 1987.

\section{"AUTHORIZATION OF APPROPRIATIONS}

42 USC 10269.

"SEC. 509. Notwithstanding subsection (d) of section 302, and subject to subsection (e) of such section, there are authorized to be appropriated for expenditures from amounts in the Waste Fund established in subsection (c) of such section such sums as may be necessary to carry out the provisions of this title.

\section{"TERMINATION OF THE BOARD}

42 USC 10270.

"SEC. 510. The Board shall cease to exist not later than 1 year after the date on which the Secretary begins disposal of high-level radioactive waste or spent fuel in a repository." 


\title{
Appendix B \\ Nuclear Waste Technical Review Board Members: Curricula Vitae
}

\author{
Dr. Don U. Deere \\ Chairman
}

President Reagan appointed Dr. Deere to serve as chairman of the Nuclear Waste Technical Review Board on January 18, 1989. His term of office expires April 19, 1992.

Dr. Deere has more than 45 years of experience as an international consultant in the planning, designing, and construction of shafts, tunnels, dams, underground mines, and storage projects, primarily in the fields of engineering geology and rock mechanics. With more than 35 years of university teaching experience and approximately 50 professional papers, he is presently an adjunct full professor in the Department of Civil Engineering and the Department of Geology at the University of Florida.

Dr. Deere consults extensively, both in the United States and overseas, for private and governmental organizations on civilian and defense projects. In the past, he provided services to Fenix and Scisson and the U.S. Atomic Energy Commission on the design of underground openings for nuclear tests at the Nevada Test Site. He also has worked on numerous nuclear power plant projects. Currently, Dr. Deere advises the U.S. Bureau of Reclamation on aspects of the New Waddel Dam near Phoenix, Arizona, and serves as consultant on the design and construction of the Washington, D.C., metro system, a position he has occupied for the past 23 years.

He has also consulted on various aspects of several dozen hydroelectric engineering projects in many foreign countries including Argentina, Brazil, Canada, Chile, Colombia, Costa Rica, the Dominican Republic, Ecuador, Egypt, Greece, the British Colony of Hong Kong, Israel, Mexico, Panama, Peru, Rhodesia, Turkey, Venezuela, and New Zealand.

Dr. Deere received the BEAVER Award in January 1990 and the MOLES Award in 1983 for Outstanding Achievement in Construction. In March 1990 he 
will receive the Rock Mechanics Award of the Society of Mining Engineers. In 1987, he participated in a National Academy of Sciences committee, which evaluated and proposed the final list of possible locations for the Superconducting Super Collider. He was elected to the National Academy of Engineering (1966), the National Academy of Sciences (1971), the National Academy of Sciences of Argentina (1987), and is a member of numerous professional societies.

He received a B.S. in mining engineering from Iowa State College (1943), an M.S. in geology from the University of Colorado (1949), and a Ph.D. in civil engineering from the University of Illinois (1955).

He resides in Gainesville, Florida. 


\section{Dr. Clarence R. Allen}

President Reagan appointed Dr. Allen to serve on the Nuclear Waste Technical Review Board on January 18, 1989. His term expires April 19, 1992.

Dr. Allen is presently a professor of geology and geophysics at the California Institute of Technology where he has served as director of the Seismological Laboratory, chairman of the Division of Geological Sciences, and chairman of the faculty. He has more than 40 years of teaching experience and is the author of more than 120 professional publications.

Over the last 25 years, Dr. Allen has served in a variety of capacities on almost 30 advisory committees and professional boards including: the National Academy of Sciences' Board on Radioactive Waste Management, Panel on Earthquake Prediction, Geology Section and Commission on Physical Sciences, Mathematics, and Resources; as chairman of the National Earthquake Prediction Evaluation Council; chairman of the National Science Foundation's Earth Science Advisory Panel; and chairman of the California State Mining and Geology Board.

He also has been a consultant on major dams and nuclear power plants located throughout the world including Argentina, Brazil, Canada, Chile, Costa Rica, Egypt, Haiti, Iran, Iraq, Pakistan, Paraguay, Peru, the Philippines, Tunisia, the United States, and Venezuela. Dr. Allen has conducted field research in Chile, China, Indonesia, Japan, Mexico, New Zealand, the Philippines, Taiwan, Tibet, Turkey, the United States, and Venezuela.

Dr. Allen received the first G.K. Gilbert Award in Seismic Geology from the Carnegie Institution of Washington. He has served as president of both the Geological Society of America and the Seismological Society of America and was elected to the American Academy of Arts and Sciences (1974), the National Academy of Engineering (1976), and the National Academy of Sciences (1976).

$\mathrm{He}$ is a fellow of the Geological Society of America and the American Geophysical Union and a member of six other professional societies. His wideranging research interests include seismicity, tectonics of fault systems, geologic hazards, earthquake prediction, siting of critical facilities, and geophysical studies of glaciers.

Dr. Allen is a Phi Beta Kappa graduate from Reed College (1949), where he received a B.A. in physics. He subsequently received an M.S. in geophysics (1951) and a Ph.D. in structural geology and geophysics (1954) from the California Institute of Technology.

Dr. Allen resides in Pasadena, California. 


\section{Dr. John E. Cantlon}

President Reagan appointed Dr. Cantlon to serve on the Nuclear Waste Technical Review Board on January 18, 1989. His term expires April 19, 1992.

As vice president for Research and Graduate Studies and dean of the Graduate School at Michigan State University, Dr. Cantlon brings to the Board more than 20 years of academic and administrative experience at Michigan State University. After serving six years as academic vice president and provost, he was appointed to his present position. Dr. Cantlon also has served as director of the Environmental Biology Program at the National Science Foundation.

Over the last 30 years Dr. Cantlon has served on almost two dozen advisory committees with various academic, government, and private organizations including the White House, Department of Energy, National Academy of Sciences, Environmental Protection Agency, National Science Foundation, Oak Ridge National Laboratory, World Resources Institute, and the Boyce Thompson Institute. Most recently he participated in a National Academy of Sciences' committee, which evaluated and proposed the final list of possible locations for the Superconducting Super Collider.

Dr. Cantlon is a member of more than a dozen professional organizations and societies. In particular, he has served as president of the Ecological Society of America; president of the Michigan Academy of Science, Arts, and Letters; and chairman of the board of the Michigan Energy and Resources Research Association.

With more than 40 years of teaching and research experience at four universities and the publication of three dozen professional publications, Dr. Cantlon also is a professor of botany at Michigan State University. His diverse research interests include physiological ecology, micro-environments, Alaska tundra vegetation, and academic administration and research related to economic development.

Throughout his career Dr. Cantlon has received numerous awards including the Distinguished Faculty Award and Centennial Review Distinguished Lecturer at Michigan State University. In 1986, he was awarded the Distinguished Faculty Award by the Michigan Council of Governing Boards.

He received a B.S. in biology and chemistry from the University of Nevada (1947) and a Ph.D. in plant ecology from Rutgers University (1950).

Dr. Cantlon resides in East Lansing, Michigan. 


\section{Dr. Melvin W. Carter}

President Reagan appointed Dr. Carter to serve on the Nuclear Waste Technical Review Board on January 18, 1989. His term expires April 19, 1992.

As Neely Professor Emeritus in Nuclear Engineering and Health Physics, Georgia Institute of Technology and an international consultant on radiation protection, Dr. Carter has expertise in a broad range of issues related to radioactive waste management. He serves as a consultant to the Nuclear Regulatory Commission's (NRC) Advisory Committee on Nuclear Waste and its Advisory Committee for Reactor Safeguards and has been on hearing boards for both the NRC and the Department of Energy (DOE).

Dr. Carter also has been a consultant to almost two dozen federal and state government agencies and private companies including the DOE, UNC Nuclear Industries, NUS Corporation, Westinghouse Electric, Roy F. Weston Inc., Battelle Pacific Northwest Laboratories, EG\&G Idaho, Los Alamos National Laboratory, Coca-Cola, Homestake Mining Company, and the Georgia Department of Human Resources.

Among his many administrative posts, Dr. Carter has served as director of the Office of Interdisciplinary Programs and the Bioengineering Center at the Georgia Institute of Technology, and director of the Environmental Protection Agency's National Environmental Research Center in Las Vegas, Nevada, and the Public Health Service's Southeastern Radiological Health Laboratory in Montgomery, Alabama. In addition, he has been elected president of both the International Radiation Protection Association and the Health Physics Society, was on the board of directors of the National Council on Radiation Protection and Measurements, and has been chairman or a member of several of the Council's scientific and administrative committees.

In addition to developing and teaching a large number of graduate and undergraduate courses at the Georgia Institute of Technology over the last two decades, Dr. Carter has organized five major conferences on different types of radioactive material and has developed a dozen technical short courses on a variety of topics including radioactive waste management, radiological health and safety, toxic substances in the environment, and environmental protection.

Dr. Carter has testified before the Committee on Labor and Human Relations, U.S. Senate, and the Committee on Armed Services, U.S. House of Representatives. With nearly 100 major reports and publications to his credit, he also is editor of Environment International, a monthly scientific journal published by Pergamon Press. 
He received a B.S. in civil engineering (1949) and an M.S. in public health engineering (1951) from the Georgia Institute of Technology and a Ph.D. in radiological and environmental engineering (1960) from the University of Florida.

Dr. Carter resides in Atlanta, Georgia. 


\section{Dr. Donald Langmuir}

President Reagan appointed Dr. Langmuir to serve on the Nuclear Waste Technical Review Board on January 18, 1989. His term expires April 19, 1992.

Dr. Langmuir brings to the Board an extensive background in groundwater geochemistry. He is presently a professor of geochemistry at the Colorado School of Mines, Golden, Colorado. During his career, Dr. Langmuir has accumulated over 25 years of teaching experience at Rutgers University, Pennsylvania State University, the University of Nevada, the University of Sydney in Australia, and the Colorado School of Mines. He also has worked in the Water Resources Division of the U.S. Geological Survey.

His research interests include uranium, thorium, and radium geochemistry as it relates to radioactive waste disposal; groundwater prospecting for and in-situ leaching of ore deposits; mechanisms and modeling of metal and ligand sorption and solution-mineral equilibria in the saturated and unsaturated zones; thermodynamic and kinetic properties of water-rock systems; acid-rain weathering of building materials; and groundwater pollution.

Over the last 10 years Dr. Langmuir has served on or been chairman of almost a dozen expert panels on various research programs sponsored by the Department of Energy, Nuclear Regulatory Commission, Environmental Protection Agency, and Lawrence Berkeley Laboratory. He is presently president of the 7,500member Colorado Mountain Club.

With memberships in nearly a dozen professional societies, Dr. Langmuir has served as chairman of numerous society committees and sessions of national meetings related to hydrology and geochemistry and prepared several symposia and short courses. He is a fellow of the Mineralogical Society of America and the American Association for the Advancement of Science. Dr. Langmuir also has been associate editor of Geochimica et Cosmochimica Acta, the journal of the Geochemical Society, and served on the editorial board of Interface, the journal of the Society of Environmental Geochemistry and Health.

Over the last two decades, Dr. Langmuir has published nearly 80 professional papers and articles and been awarded 23 grants and contracts supporting \$1.7 million worth of research. He has consulted for clients in 15 U.S. states and in Australia, Canada, France, and Sweden.

He is a cum laude graduate of Harvard University (1956) where he received an A.B. in geological sciences. After serving as a naval officer, he subsequently received an M.A. (1961) and a Ph.D. (1965) in geology from Harvard University.

Dr. Langmuir resides in Golden, Colorado. 


\section{Dr. D. Warner North}

President Reagan appointed Dr. North to serve on the Nuclear Waste Technical Review Board on January 18, 1989. His term expires on April 19, 1990.

Dr. North is a principal with Decision Focus Inc., Los Altos, California; a consulting professor in the Department of Engineering-Economic Systems at Stanford University; and associate director of the Stanford Center for Risk Analysis. Prior to his employment with Decision Focus, he spent 10 years with SRI International in Menlo Park, California.

Dr. North's area of expertise is risk analysis and decision analysis. He has carried out applications to a wide variety of public policy issues, including: weather modification, wildland fire protection, biological quarantine for the U.S. space program, disposal of chemical munitions and agents, planning of energy systems and energy research and development, and risk assessment and management of toxic chemicals. Dr. North serves on the editorial boards for Risk Analysis, Risk Abstracts, and Management Science.

Dr. North directs the environmental activities for Decision Focus, Inc. The firm has carried out environmental risk assessments and developed and implemented risk management decision frameworks for the Electric Power Research Institute and numerous electric utilities, energy companies, chemical companies, industry associations, the Department of Energy, and the Environmental Protection Agency.

Dr. North served as a consultant on decision analysis to the National Academy of Sciences (NAS) for its review in 1986 of the Department of Energy (DOE) methodology used to select prospective sites for the Nation's first geologic repository for high-level radioactive waste. Dr. North has participated in six other NAS studies on environmental risk issues, including those resulting in the reports Risk Assessment in the Federal Government: Managing the Process (1983) and Improving Risk Communication (1989). Dr. North currently serves on the NAS Committee on Risk Assessment Methodology.

Dr. North has served on committees of the Science Advisory Board (SAB) of the Environmental Protection Agency (EPA) continuously over the past 10 years. He currently is vice chair of the Environmental Health Committee, and during 1988-89 he was the chair of the Global Climate Change Subcommittee for the SAB review of two EPA reports to Congress on climate alteration from carbon dioxide and other radiatively active gases in the atmosphere. Dr. North also has been a reviewer of the carcinogen risk assessment guidelines, chair of the subcommittee that reviewed EPA's risk assessment research, and vice chair of the subcommittee that advised EPA on the congressionally mandated revision of the Hazard Ranking System used to select Superfund sites. From March 1987 to June 
1989, Dr. North was a member of the California Governor's Scientific Advisory Panel for the Proposition 65 Toxics Initiative, passed in 1986.

Dr. North received a B.S. in physics from Yale University (1962) and three advanced degrees from Stanford University: an M.S. in physics (1963), an M.S. in mathematics (1966), and a Ph.D. in operations research (1970).

He resides in Woodside, California. 


\section{Dr. Dennis L. Price}

President Reagan appointed Dr. Price to serve on the Nuclear Waste Technical Review Board on January 18, 1989. His term expires April 19, 1990.

Dr. Price is now a professor of industrial engineering and operations research, director of the Safety Projects Office, and coordinator of the Human Factors Engineering Center at Virginia Polytechnic Institute and State University (VPI). With more than 20 years of teaching experience at three institutions and eight years of industrial experience with two corporations, his present interests include transportation of hazardous materials, human factors research, engineering psychology, industrial hazard control, design and evaluation of man-machine systems, and systems safety analysis.

Since 1977 , Dr. Price has been a human factors/safety engineering consultant for a variety of clients including: Florida Power and Light, U.S. Navy, IBM, Union Camp, Mountain West Research in Nevada, Aetna Life and Casualty, Liberty Mutual, Sears, and product liability attorneys in 10 states. He also is certified as a hazard control manager and a product safety manager.

As a member of the National Academy of Sciences' (NAS) Transportation Research Board (TRB), Dr. Price has served as chairman or been a member of six committees or subcommittees, including the chairman of the $\mathrm{A} 3 \mathrm{C} 10$ Committee on the Transportation of Hazardous Materials. In addition, he was chairman of NAS' Task Force on Pipeline Safety and a member of its Committee on Demilitarization of Chemical Weapons. For his NAS service, Dr. Price received the Distinguished Service Award (1987) and the Outstanding Service Commendation (1981).

Dr. Price's publications include more than 30 papers in the open literature, 1 book, 7 chapters in various books, and over 160 technical reports for private industry, clients, or government agencies. Some of these studies were the subjects of public hearings and radio and television programs with nationwide coverage. $\mathrm{He}$ is also on the editorial board of Human Factors, the journal of the Human Factors Society, and serves as a professional reviewer for seven different organizations. Dr. Price is a member of six professional organizations and has served on numerous university committees.

Dr. Price has a very diverse educational background with a B.A. from Bob Jones University (1952), an M.A. in psychology from California State University at Long Beach (1967), and a Ph.D. in industrial engineering from Texas A\&M University (1974). He also received an M.A. and B.D. from the American Baptist Seminary of the West (1955).

He presently resides in Blacksburg, Virginia. 


\section{Dr. Ellis D. Verink, Jr.}

President Reagan appointed Dr. Verink to serve on the Nuclear Waste Technical Review Board on January 18, 1989. His term expires April 19, 1990.

Dr. Verink brings to the Board more than 50 years of experience in materials selection and corrosion. He is a Distinguished Service Professor of Metallurgy, former chairman of the Materials Science and Engineering Department at the University of Florida, and president of Materials Consultants, Inc. He was elected a fellow of the Metallurgical Society (1988) and the American Society for Metals (1978).

In addition to his election to president of the Metallurgical Society, Dr. Verink also has served on the executive committee, board of directors, and board of trustees of the American Institute of Mining, Metallurgical and Petroleum Engineers. He was a three-term national director of the National Association of Corrosion Engineers and served on five National Academy of Sciences committees, including two that reviewed the conceptual geologic repository designed by Swedish engineers. Dr. Verink also has been chairman or a member of more than 20 other national committees or advisory groups.

With more than 25 years of academic experience, Dr. Verink has served as chairman of nine committees, including the Search Committee for the President of the University of Florida, and has been a member of eight other university committees. For his contributions to material sciences and university teaching, Dr. Verink was elected a fellow of the Metallurgical Society and has received nearly a dozen other awards including the Willis Rodney Whitney Award, Florida Blue Key Distinguished Faculty Award, Educator Award of the Metallurgical Society, and University of Florida Scholar of the Year Award.

As a registered professional engineer with special accreditation in corrosion engineering, Dr. Verink has been a consultant on numerous projects for private clients such as the Aluminum Association, Copper Development Association, Sandia Corporation, and the Lockheed-Georgia Co. He has been a member of American delegations to both China and the Soviet Union and has lectured in five foreign countries.

Dr. Verink has written more than 75 technical papers, edited 2 books and 9 chapters in other books, and served as corrosion editor for the Journal of the Electrochemical Society and on the editorial board of Surface Technology Magazine and Journal of Materials Education.

Dr. Verink has three educational degrees in metallurgical engineering: a B.S. from Purdue University (1941) and an M.S. (1963) and Ph.D. (1965) from Ohio State University. 
He resides in Gainesville, Florida, where he has served in the past as president of both the Kiwanis Club and the YMCA. 


\section{Appendix C People Making Presentations Before The Nuclear Waste Technical Review Board}

The following people made presentations before the Board or panel(s) from March 7 , 1989 , through December 31,1989 . This list is arranged alphabetically by organization.

Argonne National Laboratory

Argonne, IL 60439-4815

Ross C. Hemphill

(708) $972-4497$

Battelle - Columbus

505 King Avenue

Columbus, OH 43201

Pamela J. Sutherland

(614) $424-4493$

Battelle, Pacific Northwest Laboratories

P.O. Box 999

Richland, WA 99352

Michael J. Apted

Charles F. Voss

(509) 376-4601

(509) $376-5896$

Battelle, Pacific Northwest Laboratories

Suite 900, 370 L'Enfant Promenade, SW

Washington, DC 20024

Abraham E. Van Luik

(202) 646-5207
Disposal Safety, Inc.

Suite 314, 1660 L Street, NW

Washington, DC 20036

Benjamin Ross

(202) 293-3993

EG\&G Energy Measurements, Inc.

P.O. Box 1912

Las Vegas, NV 89125

Ted B. Doerr

(702) 295-0155

Thomas P. O'Farrell

W. Kent Ostler (702) 293-7762

(702) 295-0622

EG\&G Idaho

P.O. Box 1625

Idaho Falls, ID 83415

Ira $\mathrm{K}$. Hall

(208) 526-1806

Electric Power Institute

P.O. Box 10412

Palo Alto, CA 94306

Robert A. Shaw

(415) $855-2026$ 
Fenix \& Scisson of Nevada

Suite P250, 101 Convention Center Drive

Las Vegas, NV 89109

James D. Grenia

(702) 794-7985

Bruce T. Stanley
Nevada Agency for Nuclear Projects

Capitol Complex

Carson City, NV 89710

Robert R. Loux

Carl A. Johnson

(702) $885-3744$

(702) $885-3744$
L. Lehman \& Associates, Inc.,

Suite 209, 1103 W. Burnsville Parkway

Minneapolis, MN 55337

Linda L. Lehman

(612) $894-0357$

Lawrence Livermore National Laboratory

P.O. Box 808

Livermore, CA 94550

William E. Glassley $422-6499$

Richard A. Van Konynenburg (415) 422-0456

Los Alamos National Laboratory

Las Vegas, NV 89109

Bruce M. Crowe

(702) 794-7096

Hemendra N. Kalia

(702) $794-7815$

Los Alamos National Laboratory

Los Alamos, NM 87545

David E. Hobart

(505) 843-9313

Arend Meijer

Thomas J. Merson

A. Edward Norris

(505) 843-0675

(505) $667-5726$

(505) $667-5442$

Robert S. Rundberg

(505) 667-4559

Mifflin \& Associates, Inc.

Suite C25, 2700 East Sunset Road

Las Vegas, NV 89120

Martin D. Mifflin

(702) 798-0402

Maurice E. Morgenstein

Don L. Shettel, Jr.

(702) 798-0402

(702) 798-0402
Northeast Utilities

P.O. Box 270

Hartford, CT 06141

C. Frederick Sears

(203) $665-3758$
Oak Ridge National Laboratory

P.O. Box 2008

Oak Ridge, TN 37831

Ronald B. Pope

(615) 574-6461

David S. Joy

(615) $576-2068$

\section{RE/SPEC}

3815 Eubank Northeast

Albuquerque, NM 87011

Paul F. Gnirk

(505) 268-2661

Reynolds Electrical and Engineering Company P.O. Box 98521

Las Vegas, NV 89193-8521

Robert F. Pritchett

(702) 794-7561

Science Applications International

Corporation (SAIC)

101 Convention Center Drive

Las Vegas, NV 89109

William B. Andrews

(702) 794-7803

G. Kenton Beall

(702) 794-7829

Monica M. Dussman

(702) 794-7799

Gregory A. Fasano

(702) 794-7793

Ernest L. Hardin

(702) $794-7617$

Jerry L. King 
Grover H. Prowell

David Stahl

Michael D. Voegele

Jean L. Younker

\section{U.S. Bureau of Reclamation, Denver Office}

Box 25007

Denver, CO 80225

David W. Harris

Mark H. McKeown

(303) 236-8098

(303) $236-0661$

\section{U.S. Department of Energy}

1000 Independence Avenue, SW

Washington, DC 20585

Secretary James D. Watkins

(202) $586-6210$

\section{U.S. Department of Energy, Chicago \\ Operations Office \\ 9800 South Cass Avenue}

Argonne, IL 60439

Judith Holm

Michael J. Klimas

Jeffrey B. Roberts

Robert S. Rothman

(708) $972-2410$

(708) $972-2134$

(708) $972-2228$

(708) $972-2694$

\section{U.S. Department of Energy, Office of Civilian}

Radioactive Waste Management

1000 Independence Avenue, SW

Washington, DC 20585

Donald $\mathrm{H}$. Alexander

Gordon J. Appel

Lake H. Barrett

Stephen J. Brocoum

William J. Danker

Elizabeth Darrough

Steven E. Gomberg

H. Jackson Hale

Thomas H. Isaacs

Keith A. Klein
(202) $586-6497$

(202) $586-9322$

(202) $586-2277$

(202) $586-5731$
Christopher A. Kouts

(202) 586-2285

Ram D. Lahoti

(202) $586-4099$

Gerald J. Parker

(202) $586-5679$

Samuel Rousso

(202) $586-6850$

Jerome D. Saltzman

Ralph Stein

(202) 586-9692

(202) 586-6046

U.S. Department of Energy, Idaho, Civilian Radioactive Waste Branch

785 DOE Place

Idaho Falls, ID 83402

Mark S. Pellechi

(208) $526-9916$

U.S. Department of Energy, Office of Fusion Energy

Washington, DC 20545

John W. Willis

(301) $353-4095$

U.S. Department of Energy, Sandia National Laboratories

P.O. Box 5800

Albuquerque, NM 87185

Felton W. Bingham

(505) $844-8816$

Jonathan W. Cashwell

(505) $845-8101$

Paul G. Kaplan

(505) $846-1815$

Robert Luna

(505) $845-8422$

K. Sieglinde Neuhauser

(505) $845-8246$

Joe R. Tillerson

Marilyn M. Warrant

(505) $844-5575$

(505) $845-8542$

U.S. Department of Energy, Sandia National Laboratories

Suite 860, 101 Convention Center Drive

Las Vegas, NV 89109

Scott Sinnock

(702) $794-7200$ 
U.S. Department of Energy, Yucca Mountain Project Office

P.O. Box 98518

Las Vegas, NV 89193-8518

Maxwell B. Blanchard

(702) 794-7939

Michael Owen Cloninger

(702) 794-7847

David C. Dobson

Carl P. Gertz

Leonard J. Owens

John K. Robson
(702) $794-7940$

(702) 794-7920

(702) 295-0900

(702) 794-7933

\section{U.S. Environmental Protection Agency}

401 M Street, SW

Washington, DC 20460

Raymond L. Clark

(202) 475-9633

\section{U.S. Geological Survey}

Federal Building, Room 224

705 North Plaza Street

Carson City, NV 89701

Otto Moosburner

(702) $887-7600$

\section{U.S. Geological Survey \\ P.O. Box 327}

Mercury, NV 89023

Alan L. Flint

(702) 295-5805

\section{U.S. Geological Survey, Denver Office}

P.O. Box 25046

Denver, CO 80225

William W. Dudley, Jr.

Dwight T. Hoxie

Joseph P. Rousseau

Robert C. Trautz

Edwin P. Weeks

William E. Wilson

(303) $236-4920$

(303) 236-5019

(303) $236-5183$

(303) $236-5308$

(303) 236-4981

(303) $236-4920$

U.S. Nuclear Regulatory Commission 11555 White Flint North

Rockville, MD 20814

Robert E. Browning

(301) 492-3404

University of California

4101 Etcheverry Hall

Berkeley, CA 94720

Thomas H. Pigford

(415) $642-6469$

University of Nevada

Reno, NV 89557

John W. Bell

(702) 784-6691

Michael A. Ellis

John W. Fordham

Lawrence T. Larson

Lonnie C. Pippin

David E. Rhode

Richard A. Schweickert

Scott W. Tyler

(702) $784-6610 / 1382$

(702) $673-7364$

(702) 784-4002

(702) 673-7306

(702) 673-7310

(702) 784-6901

(702) 673-7391

University of Nevada

4505 Maryland Parkway

Las Vegas, NV 89154-4010

Eugene I. Smith

(702) $739-3262$

Weston

955 L'Enfant Plaza, SW

Washington, DC 20024

David Michlewicz

(202) 646-6659

Larry Rickertsen

(202) 646-6760 


\section{Appendix D \\ Panels and Working Papers}

The Nuclear Waste Technical Review Board has established the following panels.

Containers and Transportation Panel

Chairperson: Dr. Dennis L. Price

Members: Dr. Melvin W. Carter

Dr. D. Warner North

Dr. Ellis D. Verink

Consultant: Dr. Phani K. Raj, President, Technology and Management Systems, Inc.

Hydrogeology and Geochemistry Panel

Chairperson: Dr. Donald Langmuir

Member: Dr. Clarence R. Allen

Consultants: Dr. Patrick A. Domenico,

- Professor, Department of Geology, Texas A\&M University

Dr. Roy E. Williams, Professor of Hydrogeology and Director, Waste Management Studies, Department of Geology, University of Idaho
Risk and Performance Analysis Panel

Chairperson: Dr. D. Warner North

Members: Dr. John E. Cantlon

Dr. Don U. Deere

Dr. Donald Langmuir

Dr. Dennis L. Price

Dr. Ellis D. Verink

Consultant: Dr. William D. Barnard, Office of Technology Assessment
Structural Geology and Geoengineering Panel

Chairperson: Dr. Clarence R. Allen

Member:

Dr. Don U. Deere

Consultants: Dr. Edward J. Cording, Professor of Civil Engineering, University of Illinois at Urbana-Champaign

Dr. William G. Melson, Department of Mineral Sciences, Smithsonian Institution

Environment and Public Health Panel

Chairperson: Dr. Melvin W. Carter

Members: Dr. John E. Cantlon

Dr. D. Warner North 
In addition to relying on information from transcripts of Board meetings, U.S. Department of Energy documents, and papers prepared by department contractors, the State of Nevada, industry, and others, the Board relied on papers prepared by the various panels to prepare this report. Panel reports adopted by the Board and used in writing this report include the following.

1. "Report to the Full Board from the Structural Geology and Geoengineering Panel," prepared by panel members Dr. Allen (chairperson) and Dr. Deere with the assistance of Dr. Cording and Dr. Melson, consultants to the panel. The report was adopted by the Board on September 13, 1989.

2. "Report to the Full Board from the Hydrogeology and Geochemistry Panel," prepared by panel members Dr. Langmuir (chairperson) and Dr. Allen with the assistance of Dr. Domenico and Dr. Williams, consultants to the panel. The report was adopted by the Board on January 9, 1990.

3. "Report to the Full Board from the Risk and Performance Analysis Panel," prepared by panel members Dr. North (chairperson), Dr. Cantlon, Dr. Deere, Dr. Langmuir, Dr. Price, and Dr. Verink with the assistance of Dr. Barnard, consultant to the panel. The report was adopted by the Board on September 13, 1989.

4. "Report to the Full Board from the Containers and Transportation Panel," prepared by panel members Dr. Price (chairperson), Dr. Carter, Dr. North, and Dr. Verink. The report was adopted by the Board on September 13, 1989.

5. "Report to the Full Board from the Environment and Public Health Panel," prepared by panel members Dr. Carter (chairperson), Dr. Cantlon, and Dr. North. The report was adopted by the Board on December 13, 1989. 


\section{Appendix E \\ Guide to Scientific and Technical Terms}

This report to Congress and the Secretary of Energy is of necessity technical in nature. The Nuclear Waste Technical Review Board (NWTRB) is aware, however, that the report will be of interest to nontechnical readers as well. For this reason, a guide to scientific and technical terms has been compiled to aid readers in understanding such terms used in the report. The guide is not meant to be a formal glossary nor to have the completeness of a dictionary, but rather, it is intended to help the reader understand in a general sense technical terms used regularly by the Board.

Accessible environment: The area outside of the designated repository boundary in either a horizontal or vertical direction.

Adsorption/desorption: As water percolates through the rocks, dissolved radionuclides and other species can attach to or detach from the surface of minerals (e.g., zeolites) by physical or chemical processes called adsorption or desorption, respectively.

Advection: The horizontal flow of water through porous and/or fractured rock formations.

Alluvium: A surface or near-surface deposit of unconsolidated or poorly consolidated gravel, sand, clays, or peats that are loosely arranged, unstratified, or not cemented together.

Amorphous silica: Forms of silicon dioxide that lack a crystalline structure.

Analog studies: Comparable technical studies done in different but similar settings, e.g., studies of underground water flow rates in a geologic media having characteristics similar to the geologic media of particular interest.
Basalt: A dark grey, brown to blackish, finegrained igneous rock that was once in a molten state.

Baseline: A known and stable standard (e.g., configuration, schedule, data, values, criteria, or budget) against which changes are measured and compared.

Block: An undeformed mountain-sized section of rock that may be bounded by large faults and/ or large-scale topographic features (e.g., river valleys).

Borings: Holes drilled into the earth, usually vertically from the surface, but may be inclined.

Bromide: A negatively charged ion of the element bromine, usually very soluble in water.

Caldera: A massive volcanic explosion, generating great quantities of volcanic ash, followed by lava withdrawal leaving localized subsidence fractures such as Crater Lake, Oregon. 
Canister: The material surrounding a waste form (e.g., spent fuel rods) that provides containment for storage, handling, and/or disposal.

Cask: A massive container used to transport and/ or store irradiated nuclear fuel or high-level nuclear waste. It provides physical and radiological protection and dissipates heat from the fuel.

Characterization: The collecting of information necessary to evaluate suitability of a region or site for geologic disposal.

Container: A receptacle designed to hold spent fuel or radioactive material to facilitate movement and storage.

Deep geologic repository: (i.e., geologic repository) A facility, at least a few hundred meters below the earth's surface, that is intended to be used for the disposal of radioactive waste.

\section{Desorption: See adsorption/desorption.}

Displacement: Differential movement such as occurs along a fault.

Disposal: The isolation of radioactive materials from the accessible environment with no foreseeable intent of recovering it. Isolation occurs through a combination of man-made and natural barriers, rather than by human control. The Nuclear Waste Policy Act of 1982 specifies emplacement in mined geologic repositories.

Down-reaming: Mechanically enlarging a hole or small vertical shaft in the earth from the surface down.

Drift: A near-horizontal, linear tunnel through the earth.
Drill-and-blast excavation: The excavation of openings in the earth using explosives emplaced in drilled holes.

Fault: A plane in the earth along which differential slippage of the adjacent earth has occurred, causing surface or near-surface ground rupture.

Ferric oxyhydroxide: A mineral which can become various forms of iron oxides (i.e., rust) depending on the amount of water in the mineral.

Fracture: Any break in a rock (i.e., a crack, joint, fault), whether or not accompanied by displacement.

From-reactor casks: Casks for shipping spent fuel from reactor sites to the repository or the monitored retrievable storage facility if such exists.

G-tunnel: A tunnel at the Nevada Test Site, Ranier Mesa, excavated by the U.S. Defense Nuclear Agency in both welded and nonwelded tuff.

Geochemical techniques: Scientific and analytical procedures employed in the study of the distribution and amounts of chemical and isotopic species in minerals, ores, rocks, soils, and waters on the basis of their chemical and physical properties.

Geologic block: Also known as a fault block. A region of the earth's surface that is bounded by nearly vertical faults.

Ghost Dance Fault: A near vertical north-south trending fault that crosses the eastern side of the Yucca Mountain geologic block.

Granite: A generally light-colored, coarsegrained igneous rock composed chiefly of two miner- 
als-quartz and feldspar, usually accompanied by a mica mineral.

Ground motion: Movement of the ground, resulting from earthquake activity, measured in terms of acceleration, velocity, or displacement.

Groundwater table: The upper surface of the zone of water saturation in rocks, below which all connected interstices and voids are filled with water.

Groundwater travel time (GWTT): The time required for a radionuclide to travel from the disturbed zone inside the repository area to the accessible environment beyond the boundaries of a repository.

High-level waste (HLW): The highly radioactive material resulting from the reprocessing of spent nuclear fuel. This includes liquid waste produced during reprocessing and any solid material derived from such liquid waste. Spent fuel can also be considered HLW if it is disposed of without reprocessing.

Holocene epoch: That period of geologic time extending from 12,000 years ago until the present.

Infiltration: The passage of fluids through small connected gaps or openings in rock formations (e.g., rainwater infiltrates into and through loosely compacted soil).

Interim storage or storage: Temporary storage of high-level waste with the intention and expectation that the waste will be removed for subsequent treatment, transportation, and/or isolation.

Isotope: A class of atomic species, of a given element, having differing atomic weights but identical atomic numbers and the same or closely related chemical properties.

Kaolinite: A common clay mineral that is characterized by a two-layer crystal structure.

Metric ton: 1,000 kilograms; about 2,200 pounds.

Metric ton of uranium (MTU): Measure of weight equivalent to about 2,200 pounds of uranium loaded into a reactor as fresh fuel.

MGDS: Mined Geologic Disposal System. A term from OCRWM's Environmental Program Overview referring to all the mined and manmade facilities required for the disposal of radioactive waste in a geologic repository.

Millirem: One-thousandth of a rem. In the International System of Units, this would be equal to 0.00001 sieverts. (See definition for rem.) In the U.S. the average person is exposed to about 360 millirems of radiation per year, 82 percent of which comes from natural background sources.

Miocene epoch: The period of geologic time extending from 24 million to 5 million years ago.

Neutron probe: An instrument for measuring water content of soil and rock, as indicated by the scattering and absorption of neutrons emitted from a probe lowered into a drill hole.

Non-welded tuff: A tuff that has not been consolidated and welded together by temperature, pressure, or a cementing mineral.

NTS: Nevada Test Site. A geographic area located in southern Nevada that is owned and operated by the U.S. Department of Energy and devoted primarily to the underground testing of nuclear devices. 
Nuclide: An atom characterized by the number of neutrons and protons and sometimes by the energy state in its nucleus.

Packaging: The act of preparing spent nuclear fuel for handling, storage, shipment, and/or disposal.

Perched water: Unconfined groundwater separated from an underlying main body of groundwater by an impervious geologic zone.

Percolation: The passage of liquids gradually through the small spaces of a porous medium.

Performance allocation: The process whereby components of the proposed repository system are assigned expected quantified levels of performance criteria.

Performance assessment: The process used to confirm whether or not specified levels of performance are met.

Person-rem: A unit of population dose equivalent obtained by multiplying the dose equivalent in rem by the population exposed. (See definition for rem.) In the International System of Units, this would be expressed in person-sieverts.

Pliocene epoch: That period of geologic time extending from 5 million to 2 million years ago.

Postclosure: That time, subsequent to the backfilling of the repository, required for the sealing of all openings and the marking of the site for future generations.

Preclosure: That time prior to the back-filling of the repository.
Probabilistic: Refers to the likelihood that an event will occur over a specified period of time.

QA: Quality assurance. The management process used to control and assure the quality of work performed.

Radioisotope: An isotope of an element that emits a particle or radiation at a measurable rate.

Radionuclide: An unstable radioactive nuclide that decays toward a stable state at a characteristic rate by the emission of particles or ionizing radiation(s).

Radionuclide migration: The measurable or predictable movement of radionuclides, generally by liquids or gases, through a rock formation.

Raise-boring: A technique of boring a shaft through rock by pulling a large diameter rotating cutterhead up through a small diameter hole.

Recharge: The act of refilling to capacity a porous medium with liquids.

Rem: A dosage of ionizing radiation that produces a biological effect approximately equal to that produced by one roentgen of $\mathrm{x}$-ray or gamma ray radiation. A millirem is one onethousandth of a rem. In the U.S., the average person is exposed to about 360 millirems of radiation per year, 82 percent of which comes from natural background sources. A jet plane trip of about 2,500 miles exposes a person to an additional 1 millirem of radiation.

Repository: A site and associated facilities designed for the permanent isolation of highlevel radioactive waste and spent nuclear fuel. It includes both surface and subsurface areas 
where high-level radioactive waste and spent nuclear fuel handling activities are conducted.

- Repository horizon: A particular geologic sequence or layer where radioactive waste is intended for disposal. The Yucca Mountain repository horizon is 900 to 1,200 feet beneath the surface of the mountain.

Risk: Possibility of suffering harm or loss due to some event. The magnitude of the risk depends on both the probability of occurrence of an event and the consequences should the event occur.

Saturated rock: A rock in which all of the connected interstices or voids are filled with water.

Seismicity: (i.e., seismic activity) Pertaining to an earthquake or earth vibration.

Sensitivity analysis: The process of varying an independent variable in a calculation and observing the relative effect on the final answer.

Shaft: A near-vertical opening excavated in the earth's surface.

Shaft-boring: A mechanical technique for excavating a shaft using a large rotating cutterhead.

Smectite: A common clay mineral-also called montmorillonite-that may be derived from volcanic glass. It is characterized by a threelayer crystal structure and has a high capacity to expand when saturated and to adsorb positive ions.

Sorption: The deposition or uptake of radionuclides or other species from gas or solution onto geologic materials (e.g., granite, basalt, tuff).
Sorption characteristics: Attributes exhibited by rocks and minerals that affect the deposition and/or uptake of radionuclides or other species on their surfaces.

Spent nuclear fuel: An irradiated fuel element not intended for further use in a nuclear reactor.

Stochastic: Refers to randomness or unpredictability of occurrence. In math, a process in which a sequence of values is drawn from a corresponding sequence of jointly distributed random variables.

Stochastic model: A model whose inputs and outputs are both uncertain and therefore described in terms of probability of occurrence.

Suballuvial: Beneath the alluvium. (See definition of alluvium.)

Subsurface water: All water beneath the land surface and beneath bodies of surface water.

Surficial fracture: A fracture occurring on the surface, such as the surface of an excavation in rock.

Tracer: An identifiable species or substance (e.g., a dye or radionuclide) mixed in water to help define the water's movement.

Tuff: A rock composed of compacted volcanic ash. It is usually porous and often relatively soft.

Tunnel boring: A technique for boring horizontally.

Unsaturated rock: A rock in which some or all of the connected interstices or voids are filled with air. 
Unsaturated zone: Those rocks/geologic formations that are located above the regional groundwater table.

Volcanic lineament: A linear topographic feature linking volcano cones or vents.

Volcanic intrusion: The upward injection or emplacement of molten rock into existing surface formations from within the earth.

Volcanism: The process by which molten rock and its associated gases rise from within the earth and are extruded on the earth's surface and into the atmosphere.

Waterborne: Floating on or carried by water.

Welded tuff: A tuff that has been consolidated and welded together by heat, pressure, and possibly the introduction of cementing minerals.
Zeolites: (zeolite minerals) A large group of white, faintly colored, or colorless silicate minerals characterized by their easy and reversible loss of water or hydration, their ready swelling when heated, and their high adsorption capacity for dissolved metal ions in water. They primarily occur in basalts and tuffs.

${ }^{3} \mathbf{H}$ : Tritium. A radioisotope of hydrogen with two neutrons and one proton in its nucleus. It has a half-life of 12.26 years and decays to an isotope of helium.

${ }^{14} \mathrm{C}$ : A radioisotope of carbon with a half-life of about 5,600 years.

${ }^{18} \mathrm{O}$ : A stable (non-radioactive) isotope of oxygen.

${ }^{36} \mathrm{Cl}$ : A radioisotope of chlorine with a half-life of $4 \times 10^{5}$ years. 